\title{
The Contribution of Human Herpes Viruses to $\gamma \delta$ T Cell Mobilisation in Co-Infections
}

\author{
Fanny Martini (D) and Eric Champagne*
}

check for

updates

Citation: Martini, F.; Champagne, E. The Contribution of Human Herpes Viruses to $\gamma \delta$ T Cell Mobilisation in Co-Infections. Viruses 2021, 13, 2372. https://doi.org/10.3390/v13122372

Academic Editor: Philippe Georgel

Received: 3 November 2021

Accepted: 24 November 2021

Published: 26 November 2021

Publisher's Note: MDPI stays neutral with regard to jurisdictional claims in published maps and institutional affiliations.

Copyright: (c) 2021 by the authors. Licensee MDPI, Basel, Switzerland. This article is an open access article distributed under the terms and conditions of the Creative Commons Attribution (CC BY) license (https:/ / creativecommons.org/licenses/by/ $4.0 /)$.
Infinity, Université Toulouse, CNRS, INSERM, UPS, CEDEX 03, 31024 Toulouse, France; fanny.martini@inserm.fr
* Correspondence: eric.champagne@inserm.fr; Tel.: +33-562-748-369

\begin{abstract}
T}$ cells are activated in viral, bacterial and parasitic infections. Among viruses that promote $\gamma \delta$ T cell mobilisation in humans, herpes viruses (HHVs) occupy a particular place since they infect the majority of the human population and persist indefinitely in the organism in a latent state. Thus, other infections should, in most instances, be considered co-infections, and the reactivation of $\mathrm{HHV}$ is a serious confounding factor in attributing $\gamma \delta \mathrm{T}$ cell alterations to a particular pathogen in human diseases. We review here the literature data on $\gamma \delta \mathrm{T}$ cell mobilisation in HHV infections and co-infections, and discuss the possible contribution of HHVs to $\gamma \delta$ alterations observed in various infectious settings. As multiple infections seemingly mobilise overlapping $\gamma \delta$ subsets, we also address the concept of possible cross-protection.
\end{abstract}

Keywords: gamma delta T cells; lymphocytes; herpes virus; CMV; HHV; co-infections

\section{Introduction}

Viruses of the human herpes viridae (HHV) group have been co-existing with humans for millions of years, and existed in primates before the split of hominids and chimpanzees [1]. Eight species infect humans [2,3]: herpes simplex 1 (HSV-1/HHV-1), herpes simplex 2 (HSV-2/HHV-2), varicella-zoster virus (VZV/HHV-3), Epstein-Barr virus (EBV/HHV-4), human cytomegalovirus (CMV/HHV-5), herpes virus 6A and 6B (HHV-6A/B), herpes virus 7 (HHV-7) and Kaposi's sarcoma virus (KSV/HHV-8). They are enveloped viruses with a large $(125-235 \mathrm{~kb})$ double-stranded DNA genome $[4,5]$. They perform a lytic cycle in epithelial cells which allows viral production, transmission and finally survival of the species. Immune responses normally control this infection, but HHVs share the capacity to persist indefinitely in the organism in a latent form with no or very limited viral replication. They can reactivate after the triggering of latently infected cells, leading to viral production and dissemination. An overt symptomatic reactivation remains a rather rare event considering the high prevalence of herpes family virus carriage in the population. With the exceptions of HSV-2 and KSV, HHV infections are ubiquitous. Most individuals worldwide become infected during the first decade of life and carry at least one HHV asymptomatically. Viruses of this family can thus be considered as part of the normal microbiome as well as the mucosal or cutaneous bacterial flora. The long-term co-evolution of these viruses with the hominid immune system allows the suggestion that some symbiotic relationship may have been established to be postulated, with an efficient immune control of excessive viral dissemination and, on the viral side, the development of diverse immune escape mechanisms [6,7]. The consequence of HHV carriage on the immune system is probably only partially estimated. T cell responses against CMV can mobilise a large part of T cells present in the elderly, and CMV in particular is known to shape the memory $\mathrm{T}$ cell compartment [8].

This review focusses on a particular subset of non-conventional T cells which use $\gamma$ and $\delta$ clonotypic TCR chains in association with CD3 components to form their TCR. $\gamma \delta$ $\mathrm{T}$ cell subsets are mobilised in acute infections by several HHVs, with sometimes-major expansions. They are at the interface between innate and adaptive immunity, and share 
with NKT or MAIT cells a limited TCR diversity due to their usage of a small set of TCR-variable genes. This restricted diversity reflects the recognition of relatively frequent ligands for which antigen-specific clones are present at a relatively high frequency. This allows them to perform their function after limited clonal expansion. This, added to the faculty of some of them to acquire an effector potential prior to antigenic challenge, allows them to respond quickly to infections. However, some subsets show adaptive-like behaviour, with massive clonal expansions and functional plasticity [9-12]. They also share with NK cells the expression of NK receptors and the capacity to be activated by TCR-independent signals and cytokines $[9,10]$. Subpopulations expressing preferential $\mathrm{V} \gamma / \mathrm{V} \delta$ combinations show preferential tissue locations in blood, lymphoid organs or specific tissues. Changes in the distribution and frequencies of $\gamma \delta$ subsets are observed in viral, bacterial and parasitic infections, as well as in cancers. $\gamma \delta \mathrm{T}$ cells during infections can be directly cytotoxic on infected cells, inhibit pathogen replication or act as regulators of other actors of the immune response $[9,10]$.

Although $\gamma \delta \mathrm{T}$ cell subsets share common properties in different mammal species, they have diverged significantly. Differences between human and murine systems are reported for thymic differentiation processes as well as major $\gamma \delta \mathrm{T}$ cell subsets residing in blood and tissues [10]. Similarly, HHVs are strictly human with the exception of HSV1/2, which can infect mice. Homologs for CMV (MCMV), EBV/KSV ( $\gamma$-herpes virus-68, MHV68) and $\mathrm{HHV}-6 \mathrm{~A} / \mathrm{B}$ (murine roseolovirus) exist, but they recapitulate only partially the characteristics of human infections [6,13-15]. Nevertheless, our knowledge of the impact of HHVs on the evolution and specification of $\gamma \delta \mathrm{T}$ cells remains limited.

Alterations of $\gamma \delta$ subsets have been reported in the context of HHV infections and HHV-unrelated viral infections, including HIV, HCV, HEV, HBV, influenza, myxoviruses, flaviviruses and the vaccinia virus [16-18]. However, given the frequency of CMV, EBV and HHV-6 carriage in the general population, other viral infections in adults can generally be considered co-infections. The possibility of the concomitant reactivation of latent viruses constitutes a possible confounding factor for attributing $\gamma \delta$ alterations to individual viruses. In this paper, we aimed to synthesise the available data relative to the contribution of HHVs to $\gamma \delta \mathrm{T}$ cell mobilisation and alterations during viral, bacterial or parasitic co-infections. We question the possible beneficial or detrimental effects of latent viral carriage on the immune control of co-infections through cross-immunity and shaping of the $\gamma \delta \mathrm{T}$ cell repertoire. Although BK, JC and Torque Teno viruses and adenoviruses (BKV, JCV, TTV and AdV) can establish latency and reactivate in conditions similar to HHVs, infections/co-infections with these viruses are not treated in our review, since data relative to $\gamma \delta \mathrm{T}$ cells in this context are virtually absent.

\section{Frequency and Determinants of Latent Virus Reactivation}

HHV latency is characterised by the persistence of the viral genome in an episomal form in the nucleus of infected cells. This is associated with no or very low viral replication, and with the expression of a restricted set of viral latency-associated genes. Viral reactivation from latently infected cells can be induced by factors which promote cell differentiation or activation as well as extrinsic environmental stress, such as hypoxia or inflammation [19]. Factors influencing reactivation can differ depending on the main site of latency. The reactivation of neurotropic HHV-1, -2 and -3 occurs in immunocompetent individuals following emotional or physical stress or local injury of tissues innervated by infected neurons. Stimuli which promote B cell activation, but also chemotherapy, UV or $\gamma$-irradiation preferentially promote the reactivation of EBV, which establishes latency mainly in B cells. CMV frequently reactivates in monocytes and their myeloid CD34 ${ }^{+}$ precursors in multiple inflammatory contexts, in particular in situations where a strong allogeneic stimulation occurs, such as solid organ transplantation (SOT) or hematopoietic cell transplantation (HCT) [20,21]. Impairment of immune control, low T cell numbers and corticoid usage are, however, major factors of reactivation for most HHVs in the context of transplantation or the therapeutic control of inflammatory diseases [22,23]. In the absence 
of prophylaxis, and based on detectable viral DNAemia, the overt reactivation of CMV occurs in more than $50 \%$ of recipients of kidney allografts [24,25]. Reported frequencies for HSV and VSV are $53 \%$ and $4-12 \%$, respectively [26,27]. After allo-HCT, the viruses most frequently reactivated were CMV, BKV and HHV-6 [28]. Multiple reactivations are frequent, and co-reactivations can occur simultaneously or successively $[28,29]$. The detection of multiple dsDNA viruses is associated with increased mortality and morbidity [30,31].

In the absence of obvious immunosuppression, reactivations of latent viruses are reported during sepsis with a frequency similar to that observed in HCT patients [32-34], during acute respiratory distress syndrome, during viral infections, non-tuberculous mycobacterial diseases $[32,35]$ and non-infectious inflammatory contexts, such as atopic dermatitis [34] and rheumatic diseases [36].

\section{Biological Features of $\gamma \delta$ T Cells}

$\gamma \delta \mathrm{T}$ cells are the first $\mathrm{T}$ cells to appear in primary lymphoid organs during foetal development. In humans, six variable $\gamma$ genes (TRGV) and seven variable $\delta$ genes (TRDV) are functional [37,38]. In the mouse system, subsets expressing specific $\mathrm{V} \gamma / \mathrm{V} \delta$ combinations differentiate sequentially in the thymus and make their home in different epithelial tissues, such as skin, intestine, tongue, lung or uterus. This is less clear in the human system, although two types of $\gamma \delta$ T cells are clearly identified: a first wave of $\gamma \delta$ cells expressing $\mathrm{V} \gamma 9$ and $V \delta 2$ first appear in the thymus, which is followed by a wave of cells expressing other $\mathrm{V}$ gene segments which predominate at delivery. Nevertheless, a thymic output of $\gamma \delta$ T cells continues after birth [39]. $\mathrm{V} \gamma 9 \mathrm{~V} \delta 2$ cells undergo a massive post-thymic expansion, and constitute the major subset found in blood (75-90\% of $\gamma \delta \mathrm{T}$ cells) and lymph nodes in adults. In other tissues $\mathrm{V} \gamma{ }^{\text {pos }} \mathrm{V} \delta 2^{\text {pos }} \mathrm{T}$ cells $(\mathrm{V} \gamma 9 \mathrm{~V} \delta 2)$ are usually present, but are outnumbered by other $\gamma \delta$ cells expressing mainly $\mathrm{V} \delta 1$ and, less frequently, $\mathrm{V} \delta 2$ (V $\gamma 9^{\text {neg }}$ ) and $V 83$, which pair with multiple $V \gamma$ genes with some tissue-dependent skewing [40].

With rare exceptions, the molecules identified as $\gamma \delta$ TCR ligands are non-conventional MHC-related (EPCR, CD1b, CD1d, MR1, MICA, MICB and ULBP4) or MHC-unrelated self-proteins (annexin A2, ephrin A2, F1-ATPAse, hMSH2 and histidyl-tRNA synthase). Several of them are endogenous proteins which can be upregulated or expressed at the cell membrane under inflammatory or metabolic stress, or following malignant transformation. These ligands are recognised independently of associated peptides or lipids, and do not require the antigen processing machinery used for antigen presentation to $\alpha \beta$ TCRs. Few foreign antigens from pathogens have been reported to stimulate $\gamma \delta$ TCRs (see [41] for a recent review). A particular case is represented by the semi-invariant human V $\gamma 9 \mathrm{~V} 82$, most of which respond in a TCR-dependent manner to low-molecular-weight phosphorylated metabolites called phosphoantigens (PhAgs). These molecules can be endogenously produced (similar to isopentenyl pyrophosphate, IPP) or originate from bacteria or parasites (such as 1-Hydroxy-2-Methyl-2-buten-4-yl 4-diphosphate, HMBPP). V $\gamma 9 \mathrm{~V} \delta 2 \mathrm{~T}$ cell activation by PhAgs requires cell contact with cells that are accumulating them. IPP overproduction may result from alteration of the mevalonate pathway of isoprenoid synthesis following viral infection [42,43], stress or malignant transformation $[44,45]$, or experimentally after treatment with aminobisphosphonates (ABPs) [46]. HMBPP accumulation occurs upon infection with bacteria or parasites expressing the alternative 1-deoxy-D-xylulose-5-phosphate (DOXP) pathway of isoprenoid synthesis [47]. $\mathrm{V} \gamma 9 \mathrm{~V} \delta 2 \mathrm{~T}$ cell response to PhAg-expressing cells requires TCR-dependent co-recognition of isoforms of the butyrophilin family molecules BTN3A1 and BTN2A1, which can associate in multimers [48-50]. Most recent data indicate that the TCR does not bind PhAgs directly. Instead, PhAgs inside cells bind the intracellular B30.2 domain of BTN3A1, inducing a conformational change in the BTN3A1/BTN2A1 which is somehow sensed by the V $\gamma 9 \mathrm{~V} \delta 2$ TCR [50-53]. BTN recognition involves a major interaction of a framework region of the TCR $\gamma$-chain (HV4) with BTN2A1, a possible contribution of CDR2 $\delta$, and no apparent interaction of the TCR regions with the PhAgs or BTN3A1 [48,49,53]. Nevertheless, specific sequences in $\mathrm{CDR} 3 \gamma$ and $\mathrm{CDR} 3 \delta$ determine $\mathrm{PhAg}$ responses: the length of $\mathrm{CDR} 3 \gamma$ is highly 
restricted to $14 \pm 1 \mathrm{aa}$, and $\mathrm{J} \gamma \mathrm{P}$ (also called $\mathrm{J} \gamma 1.2$ ) is almost invariably used. The length of this CDR3 $\delta$ can be highly variable, but a hydrophobic residue is required in position five. The underlying mechanism is thus still incompletely understood. BTN complexes might serve to recruit unknown additional molecules or to position uncharacterised cell components for their interaction with the CDR regions of the V $\gamma 9 \mathrm{~V} \delta 2$ TCR $[41,47,54]$. Foetal $\mathrm{V} \gamma 9 \mathrm{~V} \delta 2$ thymocytes are PhAg-responsive, suggesting that $\mathrm{V} \gamma 9 \mathrm{~V} \delta 2$ lymphocytes are positively selected in the thymus for their response to PhAgs, possibly by endogenous metabolites such as IPP [38,39].

Other BTN isoforms have been shown to play a role in the tissue homing or maintenance of other $\gamma \delta$ subsets in human and murine systems in a TCR-dependent manner. Thus, a general involvement of BTN isoforms in $\gamma \delta$ T cell function and antigen recognition is suspected [55-57].

The comparison of the $\gamma \delta$ TCR repertoire in cord blood and adult blood shows a progressive clonal focussing after birth, with the accumulation and predominance of a few clonotypes. This is thought to be driven by antigenic exposure, and CMV seems to be a major factor for the expansion of non- $\mathrm{V} \gamma 9 \mathrm{~V} \delta 2$ clones (see below). These expansions display features of adaptive responses, and mainly involve private sequences [58,59]. V $\gamma 9 \mathrm{~V} \delta 2$ expansion observed after birth does not lead to substantial clonal focussing. Nevertheless, clonal or oligoclonal expansions in addition to public sequences in this subset are observable in some healthy individuals by examining V $\delta 2$ CDR3 sequences and activated memory subsets [60-69]. Alterations of the repertoire occur with aging, influenced by persistent or recurrent pathogens, particularly viruses such as HHVs, which can persist throughout life and reactivate repeatedly $[60,70]$.

Co-stimulatory, inhibitory and lymphokine receptors regulate $\gamma \delta \mathrm{T}$ cell functions (see [71] for review). Most $\gamma \delta$ T cells also express variable combinations of activatory or inhibitory natural killer receptors, including natural cytotoxicity receptors (NCRs NKp30 and $\mathrm{Np} 44)$, lectin-like receptors (NKG2A/C/D) and Ig-like receptors (activatory and inhibitory KIRs). Of special importance is NKG2D, a co-stimulatory receptor expressed on virtually all $\gamma \delta$ T cells. NKG2D binds MHC-I-related ligands MICA, MICB and ULBP1-6 in humans, which are usually absent on the cell surface but are induced by stress conditions, such as tumoral transformation and viral infection [72,73]. Following infections by most HHVs, the upregulation of some NKG2D ligands is counter-balanced by viral products which interfere with the expression of selected NKG2D ligands known to limit NK cell cytotoxicity, resulting in an overall protection of infected cells $[9,74]$. Almost all human HHVs encode proteins or microRNAs which interfere with the expression of NKG2D ligands during lytic infection, thus limiting NK cell cytotoxicity [73] with rare exceptions [3,75], underlying the importance of NKG2D ligand interactions in host-virus equilibrium.

\section{4. $\gamma \delta$ and CMV/HHV-5}

CMV infection usually occurs asymptomatically in the first months of life. When examined, 59.3\% of Ugandan infants were found to be infected by CMV after one year [76], while the figure was $21.5 \%$ in Germany [77]. Seropositivity increases from $60 \%$ in European adults to 100\% in African or Asian adults [78]. CMV replicates productively in multiple tissues, mainly fibroblasts and endothelial cells. Monocytes and CD $34^{+}$hematopoietic precursors constitute the main site of virus latency. Viral reactivation and replication from monocytes require cell stimulation and differentiation, and IFN $\gamma$ and TNF are important factors which can promote viral production and dissemination to other tissues. This process is thought to occur at a low level in healthy individuals, and is tightly controlled by immune effectors, essentially CD8 cytotoxic $\alpha \beta$ T cells and NK cells, whereas antibodies can limit dissemination to other tissues [4,7,79-81].

Expansions of $\mathrm{V} \delta 2^{\text {neg }} \gamma \delta$ cells in the context of CMV infection were first reported after kidney transplantation (KTR), and subsequently in other contexts of immunosuppression [6,82-87]. In KTR, expanded cells in blood displayed CDR3 length restriction [88] and increased CD8 expression [87,88]. A higher level of $\gamma \delta$ T cell expansion was associated 
with better control of infection [88-90]. A blood signature of CMV infection remained, characterised by elevated numbers of $V \delta 2^{\text {neg }}$ cells in blood, stable expression of a TEMRA late effector phenotype (CD45RA+, CD27- and CCR7-) and increased expression of activation markers (CD28, CD69, HLA-DR, perforin, granzyme B and CD16) and of co-inhibitory receptors PD-1, TIM-3 and LAG-3 [87,91].

The consequences of CMV infection on $\gamma \delta \mathrm{T}$ cells have also been examined after hematopoietic stem cell transplantation (HSCT) or cord blood transplantation (CBT). The reconstitution of the $\gamma \delta$ T cell pool after HSCT or CBT occurs faster than the reconstitution of the $\alpha \beta$ T cell compartment, and even faster in patients with reactivating CMV, whereas the reconstitution of $\mathrm{V} \delta 2$ cells is not changed [82]. Initial studies have examined the diversity of V $\delta 2^{\text {neg }}$ cells from HSCT patients by spectratyping CDR3 $[82,92]$, but did not detect clear differences between patients with reactivating CMV and controls [93]. However, recent investigations applying NGS technology have revealed massive proliferation of new clones which were essentially $\mathrm{V} \gamma 9^{\text {neg }} \mathrm{V} \delta 2^{\text {neg }}$ following the reactivation of CMV after HSCT [58,94,95]. Clonal amplifications mainly involved private sequences, although the occurrence of public sequences was noticed $[58,94]$. Purified V $\delta 2^{\text {neg }} \gamma \delta$ cells from patients experiencing the reactivation of $\mathrm{CMV}$, but not those from patients experiencing the reactivation of EBV, recognised specifically CMV-infected fibroblasts [82,93,96]. The roles of the TCR and NKG2D in this activation were not clear, and differed for cytotoxicity and IFN $\gamma$ release [82]. In the Scheper et al. study [92], V $\delta 2^{\text {neg }}$ cells from patients having undergone HSCT/CBT for B cell chronic leukaemia (CLL) reacted in vitro against autologous B-CLL cells, and this reactivity required CD $8 \alpha \alpha$ in addition to V $\delta 1$ TCR. Strikingly, however, transduction of the TCR from two clones highly reactive to CMV into $\alpha \beta$ T cells conferred reactivity towards the leukemic cells, but not against CMV-infected fibroblasts. In another study, expanded V $\delta 1$ did not react against autologous B-CLL cells [96]. These apparently conflicting observations suggest that different $V \delta 2^{\text {neg }}$ clones from patients could have been selected by alternative determinants, with a possible influence of the infected tissue.

An imprint of CMV is also observable in healthy carriers, who usually display higher numbers of $V \delta 2^{\text {neg }}$ cells in blood when compared to $\mathrm{CMV}^{\text {neg }}$ individuals [82,92]. Asymptomatic immunocompetent blood donors who have been exposed to CMV have a higher percentage of TEMRA cells within the V $\delta 2^{\text {neg }}$ subset $[70,82,91,97]$. Further evidence for the mobilisation of $\mathrm{V} \delta 2^{\text {neg }}$ cells by CMV comes from their expansion in neonates after in utero infection [98]: although clonal amplifications with essentially private sequences were observed, a public foetal V $\gamma 8 \mathrm{~V} \delta 1$ TCR containing germline-encoded CDR3 sequences was found amplified in all six tested CMV-infected newborns [98]. As these cells responded in vitro to CMV-infected targets and showed antiviral activity, they may participate in the control of CMV infection during foetal life [98].

An MHC-like protein, endothelial protein $C$ receptor (EPCR), has been identified as a ligand for a $\mathrm{V} \gamma 4 \mathrm{~V} \delta 5$ highly expanded clone representing $25 \%$ of blood $\mathrm{T}$ cells in a CMV-infected patient. The expression of this antigen does not seem to be modified by CMV infection [99]. Nevertheless, the TCR of this clone was later shown to bind the butyrophilin

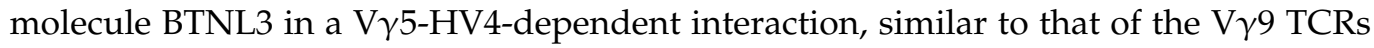
with BTN2A1, indicating a dual-modality interaction of this TCR with different ligands. Whether these different interactions contribute simultaneously or not to $\gamma \delta \mathrm{T}$ cell reactivity against CMV is currently unknown [100].

Chronic inflammation as well as aging are associated with increased oxidative stress, which promotes the reactivation of CMV; conversely, the reactivation of CMV promotes oxidative stress [101,102]. Recently, a V $\gamma 9 V \delta 1$ T cell clone expanded in a CMV-infected patient was found to recognise EphA2, an endogenous protein which is upregulated on multiple tumours and is a marker of metabolic dysregulation. EphA2 recognition involves the clonotypic regions of the TCR. This suggests that some V $\delta 1$ clones expanded in CMV infection function to detect metabolic dysfunction [103]. Three non-V $\gamma 9 \mathrm{~V} \delta 2$ clones isolated from unrelated healthy donors, expressing different $\mathrm{V} \gamma / \mathrm{V} \delta \mathrm{TCR}$ combinations, were found 
to recognise, in a TCR-dependent manner, annexin A2, an antigen upregulated on the surface cell lines and tumours following hypoxia or CMV infection [104].

Thus, the non- $\mathrm{V} \gamma 9 \mathrm{~V} \delta 2 \gamma \delta \mathrm{T}$ cell compartment displays an adaptive behaviour and CMV appears to be one major driver of clonal amplifications, possibly by inducing the expression of multiple stress ligands, which are also expressed on tumours.

\section{5. $\gamma \delta$ and EBV/HHV-4}

EBV seroprevalence is over $90 \%$ in the worldwide population [105-108]. In most instances primo-infection occurs in early childhood, and is asymptomatic due to an efficient immune control in which CD8 cytotoxic $\alpha \beta$ T cells and NK cells play a major role [109-111]. When infection takes place later in life it causes a transient symptomatic oropharynx infection, infectious mononucleosis (IM), characterised by a massive CD8 $\alpha \beta$ $\mathrm{T}$ cell expansion. EBV is an oncogenic virus responsible for lymphomas and epithelial cancers. This oncogenic potential has been reviewed elsewhere, and is not addressed in this review $[112,113]$. After the infection of B cells different sites of latency have been described, during which limited sets of latency-associated viral genes are expressed. Latency 0 (defined by viral genome persistence without transcription) and latency I (single expression of EBNA-1) states are found in cycling memory B cells and Burkitt's lymphoma (BL); latency II (EBNA1 ${ }^{+}, \mathrm{LMP}^{+}$and $\left.\mathrm{LMP2}^{+}\right)$is found in germinal centres of EBV carriers, Hodgkin's lymphoma and some in-vitro-generated EBV-infected lymphoblastoid cell lines (LCLs). Latency III (expression of multiple LMPs, EBNAs and mRNAs) is associated with EBV infection of naive B cells, lymphomas occurring in EBV-associated lymphoproliferative disease (EBV-PTLD) and most EBV-LCLs [114]. The virus infects primarily B cells, but also epithelial cells, and persists in a latent state mainly in resting memory B cells [115-117]. Occasional reactivations occur predominantly in mucosa-associated lymphoid tissue [118].

A specific reactivity of $\gamma \delta$ T cells against some EBV-infected targets is substantiated by in vitro studies. $\gamma \delta \mathrm{T}$ cells expressing $\mathrm{V} \gamma 9$-JP/V $\delta 2$ are responsive to latency I $\mathrm{EBV}^{+}$ Burkitt's lymphoma cell lines Daudi and Akata, whereas no response is observed against latency II or latency III EBV-LCLs [119,120]. Moreover, the responses to Akata and Daudi are dependent on BTN3 recognition and can be abrogated by downmodulating PhAg production with statins [46], or by blocking the TCR/CD3/BTN3 axis $[50,119,120]$. Thus, the reactivity against EBV latency I B cell lines relies at least in part on PhAg detection.

Healthy donors segregate into two populations according to the magnitude of their in vitro response to PhAgs and Akata $[62,119,120]$. This bimodality appeared to be independent of age, sex, CMV or EBV status. In one study, amplified cells seemed to also differ functionally, as $\mathrm{V} \gamma 9 \mathrm{~V} \delta 2$ from high responders produced more IFN $\gamma$ and MIP1 $\beta$, and were more cytotoxic upon stimulation. This dimorphism arises after birth prior to EBV or CMV infection, and is not found in a neonatal thymus [62]. An unknown process acting at the level of $\gamma \delta \mathrm{T}$ cell development could be involved, leading to the predominance of $\mathrm{V} \gamma$ 9-J $\gamma \mathrm{P}$ (PhAg-responsive) versus $\mathrm{V} \gamma 9-\mathrm{J} \gamma 2$ (non-responsive) rearrangements within the $\mathrm{V} \gamma 9 / \mathrm{V} \delta 2$ subset. Alternatively, early exposure to PhAgs after bacterial or parasitic infections might fashion this repertoire, including exposure to HHV-1/2, HHV-6, recurrent viral infections or vaccination (see below) [61,121].

At the acute phase of IM, patients have elevated numbers of CD8, CD4, NK, iNKT and $\gamma \delta$ cells $[119,122-124]$. V $\delta 2^{\text {pos }}$ cells are amplified in blood, display an activated phenotype $\left(\mathrm{DR}^{+}, \mathrm{CD} 38^{+}\right)$and persist for several months at the convalescent phase [125,126]. IM children were also found to segregate into two populations according to their proportion of V $\delta 2$ T cells among PBMCs at the acute phase of infection, whereas all of them had similar NK responses. This bimodality was present in EBV-seropositive children of the same age who had presumably been recently infected asymptomatically, but was not found in healthy adults who perfectly controlled EBV infection. Thus, EBV was responsible for the persistence of increased numbers of V $\delta 2 \mathrm{~T}$ cells in seropositive healthy and primo-infected children. The proportion of high responders in symptomatic IM patients was lower than that in $\mathrm{EBV}^{+}$ 
healthy children who presumably encountered EBV asymptomatically, suggesting that high $\mathrm{V} \gamma 9 \mathrm{~V} \delta 2$ responses in IM are linked to a reduced symptomatology [120].

Analyses of $\gamma \delta \mathrm{T}$ cells after HSCT also support the involvement of $\mathrm{V} \gamma 9 \mathrm{~V} \delta 2$ cells in EBV responses. In a large cohort including $110 \mathrm{EBV}^{\text {neg }}$ patients on an EBV-DNAemia basis and 22 patients with the post-HSCT reactivation of EBV [127], all patients showed a better reconstitution of the V $\delta 1$ compartment compared to $V \delta 2$, and had a predominant V81 population 2-3 months after HSCT. This was attributed to the fact that almost all individuals also experienced the reactivation of CMV. The study also pointed out that patients with higher $\mathrm{V} \delta 2$ counts experienced a lower incidence of the reactivation of EBV. Phenotypic analysis of V $\delta 2$ cells revealed expression of CD 38 and HLA-DR on V $\delta 2^{+}$cells selectively in EBV ${ }^{\text {pos }}$ patients. Thus, $\mathrm{V} \delta 2$ cells were activated following the reactivation of EBV, and may have participated in the control of EBV infection/reactivation. In contrast, another study linked an increased oligoclonality within the $\mathrm{V} \delta 1$ subset to the reactivation of EBV after allo-HSCT. However, the role of CMV was not excluded [128].

IM is generally resolutive. In rare cases, reported mainly in East Asia, it evolves on a chronic mode called chronic active EBV infection (CAEBV), with recurrent IM-like episodes. In this paediatric disorder, $\mathrm{T}$ and NK cells get infected by EBV in a context of high viral load, possibly after contacting infected B cells, and infiltrate multiple organs. These infected T/NK cells then apparently disappear to become undetectable after one year. Starting as a systemic inflammation, the disease can become malignant, leading to hemophagocytic lymphohistiocytosis (HLH) or lymphoma transformation characterised by monoclonal NK or T cell expansions [129]. Clonal expansions of EBV-infected $\mathrm{V} \gamma 9 \mathrm{~V} \delta 2 \mathrm{~T}$ cells have been observed in a form of the disease with a skin manifestation, hydroa vacciniform [130-133]. Thus, EBV infection of $\gamma \delta \mathrm{T}$ cells can occur, likely resulting from a cognate interaction between $\mathrm{V} \gamma 9 \mathrm{~V} \delta 2$ cells and infected B cells. Through the recognition of EBV-infected B cells, $\mathrm{V} \gamma 9 \mathrm{~V} \delta 2 \mathrm{~T}$ cells may participate in the control of EBV-induced lymphomagenesis. This was suggested by an in vivo model of lymphomagenesis after transferring EBV-infected human cord blood cells to NSG mice and subsequently administrating ABP-activated V $\gamma 9 \mathrm{~V} \delta 2$ cells [134].

Another manifestation of acute EBV infection is post-transplantation lymphoproliferative disorder (PTLD), a syndrome linked to immunosuppression and associated with the reactivation of EBV. In PTLD, the reactivation of EBV in B cells induces an outgrowth of infected B lymphocytes. In more advanced stages this can lead to B cell transformation and lymphomas [135]. Cases of EBV-PTLD associated with an elevated level of $\gamma \delta$ cells in blood and brain lesions have been reported [136,137]. Amplified cells belonged to the V $\delta 1$ subset [137], and were reactive to autologous EBV-LCLs in vitro. Thus, the $\gamma \delta$ cells that expand during EBV-PTLD closely resemble V $\delta 1$ cells isolated after the stimulation of normal blood with EBV-LCLs. In these studies, activation was found to be dependent on cell contact, LFA1 and the TCR/CD3 complex. The putative activating ligand was of cellular origin rather than a viral structure, and was upregulated on activated B cells. LCL-responsive clones did not show predominant CDR3 sequences, and no evidence of oligoclonal expansion was found [138-141]. Remarkably, V $\delta 1$ cells are also amplified in patients with acute B lymphocytic leukaemias [142,143], and in one study these cells were reported to lyse $\mathrm{EBV}^{\text {neg }} \mathrm{B}$-CLL cells. This suggests recognition of a cellular rather than viral determinant, but TCR-dependence of this activity was not reported [144]. A humanised murine model of EBV-lymphoproliferative disease has been used by administrating of EBV-LCL cells to B-cell-deficient Rag-/- mice. Strikingly, V $\gamma 9 \mathrm{~V} \delta 2$ cells transferred into these mice were able to prevent this experimental lymphoproliferative disease, in which transferred B cells were of a latency III type. In this work, V $\gamma 9 \mathrm{~V} \delta 2$ cells also killed EBVLCLs in vitro. Nevertheless, ABP-preactivated $\mathrm{V} \gamma 9 \mathrm{~V} \delta 2$ cells were used in vivo as well as in vitro, and their activity against EBV-LCLs was essentially mediated by NKG2D and Fas/FasL, rather than TCR-mediated [145]. 
Taken together, above studies reveal that EBV infection, symptomatic or not, can be detected by the V $\delta 2$ and the V $\delta 1$ subsets, which might contribute by recognising infected $B$ cells at different stages of maturation/differentiation.

\section{HSV1/2 Infection and Co-Infections}

HSV1 and HSV2 are reported to infect, respectively, $66 \%$ and $11 \%$ of the worldwide population [146]. HSV1/2 infect mucosal tissues in human and mice, and establish latency in ganglionic neurones after retrograde axonal transport. Most cell types can, however, be infected productively through multiple receptors, including CD4+ $\alpha \beta$ T cells [147]. In a murine model, $\gamma \delta \mathrm{T}$ cells accumulate in infected ganglia and can control lethal infection in $\alpha \beta$-deficient animals. HSV-specific $\gamma \delta$ T cell clones have been isolated, and one was found to recognise a viral antigen in an unprocessed form and in a non-MHC-restricted way. Nevertheless, the $\gamma \delta$ response in infected ganglia was polyclonal, and it was suggested that some $\gamma \delta$ T cells recognise virally induced cellular determinants [148,149]. A protective role has been ascribed to IL-17-producing $\gamma \delta$ cells in a corneal infection model, whereas $\gamma \delta$ cells were ineffective in experimental cutaneous or vaginal infections [150,151], or were shown to increase pathology [152-155]. How these observations in mice can translate to human infections is not known. No systemic expansions of $\gamma \delta \mathrm{T}$ cells as those seen with CMV or EBV have been reported for HSV1/2 in humans. However, blood $\gamma \delta$ cells from HSV-seropositive individuals expand in vitro in response to autologous HSV-infected PHA blasts $[121,156]$. In a study by Bukowski et al., expanded cells also recognised and killed Daudi BL and cells infected by the unrelated vaccinia virus, suggesting recognition of common virus-induced determinants. The reactivity was present in $\mathrm{V} \gamma 9 \mathrm{~V} \delta 2$ cells and appeared MHC-unrestricted. Retrospectively, this suggests PhAg sensing. Interestingly, Maccario et al. showed that the cytotoxicity against HSV-1 cells involved mainly conventional CD8 cells in some individuals, whereas $\gamma \delta$ cells were the main players in others, which is in line with the $\mathrm{V} \gamma 9 \mathrm{~V} \delta 2$ population dimorphism described above for responses to EBV. Cell lines derived from lesion infiltrates of HSV-1-/HSV-2-associated genital herpes patients appeared enriched in V $\gamma 9 \mathrm{~V} \delta 2 \mathrm{~T}$ cells [157]. Intriguingly, whereas EBV-LCLs are usually not targeted by $\mathrm{V} \gamma 9 \mathrm{~V} \delta 2$ cells, in the Maccario et al. study, $\mathrm{V} \gamma 9 \mathrm{~V} \delta 2$ cells killed autologous EBV-LCLs superinfected with HSV-1, suggesting a possible interaction. This was not observed in the other report [157], a discrepancy which might come from a variable efficiency of LCLs to properly express stimulatory determinants, such as BTNs, after infection.

\section{7. $\gamma \delta$ and HHV-6/7}

It is estimated that 60 to $70 \%$ of the population harbour HHV-6 and HHV-7 in their salivary gland [158]. Both viruses target primarily CD4 $\alpha \beta$ T cells, although their entry into cells is mediated by different receptors [159]. However, they can infect lymphoid, myeloid and epithelial cells. $\gamma \delta$ T cell expansions have not been reported in response to HHV-6/7 infection. In vitro, HHV-6 superinfection can reactivate EBV in Akata and P3HR-1 latently infected cells lines, and upregulates Zebra EBV early antigen in EBV-non-producer Burkitt lymphoma Raji [160]. In addition, HHV-6 can productively infect CD8 T $\alpha \beta$ cells, NK cells and $\gamma \delta$ T cells, leading to CD4 expression on $\gamma \delta$ cells and rendering them susceptible to HIV infection [161-164], a mechanism which may contribute to V $\delta 2$ depletion in AIDS (see below).

\section{8. $\gamma \delta$ and KSV/HHV-8}

$\mathrm{KSV}$ is not ubiquitous. It's prevalence in some Eastern or African areas may reach $50 \%$; however, in Western countries, the prevalence varies from 3 to $23 \%$ and is tightly linked to HIV infection, due to frequent co-transmission $[165,166]$. Similar to EBV, KSV infects primarily cells of the B lymphocyte lineage, where it can establish latency. It also shares with EBV an oncogenic potential, leading, in particular, to primary effusion lymphoma [165-167]. A role for $\gamma \delta \mathrm{T}$ cells in HHV-8 infections has been reported in one study [168], where patients selected for shedding HHV-8 in saliva $(n=7)$ were compared 
to seronegative controls. An increase in peripheral V $\delta 1$ cells was constantly observed, with a dominance of V $\delta 1$ over V $\delta 2$ in all HHV-8 infections. Expanded V $\delta 1$ cells had a terminally differentiated phenotype characterised by CD57 expression. V81-TCR CDR3 sequences analysis of seropositive individuals detected oligoclonal amplifications which were patientspecific, and thus comparable with the V $\delta 1$ amplifications observed in the context of the reactivation of CMV. These cells proliferated preferentially in vitro after stimulation of PBMC with HHV-8 viral particles and IL-2, but also with several viral proteins, although in a weaker fashion. $T$ cell lines derived from these individuals increased their lymphokine production when stimulated by the HHV-8-infected cells and several individual recombinant HHV-8 proteins. This response was diminished by the presence of anti-CD3 antibodies. However, activation was measured in the presence of PBMCs or bystander B cells (BJABs), which could have captured viral particles and/or produced cytokines, thus leaving open the possibility that V $\delta 1$ recognised virus-induced determinants.

\section{VZV/HSV-3 Infection}

In temperate countries, $90 \%$ of the population is infected with VZV by adolescence, while inhabitants of tropical countries are infected later in life [169]. The reactivation of CMV in heart transplant recipients is a risk factor for the reactivation of VZV. Interestingly, VZV upregulates the NKG2D ligand MICA on the surface of infected cells, possibly stimulating NK cells (reviewed in [170]). Recurrent aphthous ulcers are mucosal lesions which have been associated with VZV infections and reactivation, even though other infections could possibly be involved. Increased $\gamma \delta$ cells were found in blood during their exacerbation periods [171,172]. An infiltrate of $\gamma \delta \mathrm{T}$ cells, but also conventional T cells, was found in lesions by immunocytochemistry. The $\gamma \delta$ subset putatively involved is unknown [173].

\section{HHV Co-Infections}

In the context of immune suppression and transplantation, the infection/reactivation of multiple HHVs is frequent, CMV-HHV-6 being the most frequent co-infection $[29,174]$. In solid organ transplantation or HSCT, the reactivation of HHV-6 is frequently detected earlier than CMV and is a predictive factor for the reactivation of CMV [175-179]. After cord blood transplantation, HHV-6 usually reactivates after EBV [180]. HHV-6/7 infections increase the symptomatology associated with CMV, and HHV-7 increases the frequency of CMV disease [160]. The frequency of EBV-CMV co-infection post-transplantation varies between clinical studies, from 2.6 to $32.7 \%$ [31,179,181]. In the clinic, primary EBV infection does not reactivate $\mathrm{CMV}$, but primary CMV infection may induce the reactivation of EBV [182-184]. In vitro, B cells infected by EBV are more susceptible to HHV-6 infection, and superinfection by HHV-6 can reactivate EBV [160]. The increased syncytia formation due to the formation of complexes between the glycoproteins gH (CMV) and gL (HHV-6) may play a role in the increased pathogenicity of co-infection by increasing viral spread [185]. TNF induced during HHV-6 infection was proposed to mediate the reactivation of CMV in solid organ transplantation [186]. In vitro, CMV can reactivate EBV in BJAB and P3HR-1 Burkitt's lymphoma cell lines [187].

In spite of these multiple interactions, how co-infections with multiple HHVs affect $\gamma \delta$ compartments is not known. Analysis of $\gamma \delta$ T cells' cross-reactivity against different HHVs is reported in few instances $[88,168,188]$. In one case, clones reacting against CMV did not proliferate in response to fibroblasts infected by HSV or VZV $[88,188]$. Nevertheless, in view of findings reported above, CMV-reactive and HSV-reactive $\gamma \delta$ cells are recruited among different $\gamma \delta$ subsets, and the targeting of VZV by any $\gamma \delta$ subset is still uncertain. Interestingly, HHV- 8 infection could be targeted by V $\delta 1$ cells, which were found to be unreactive against CMV [168]. It is possible that fundamentally different strategies are used for the recognition of these two HHVs by $\gamma \delta$ cells. Indeed, direct recognition of viral particles is suggested in the case of HHV-8, whereas recognition of endogenous proteins is currently a preferred model in the case of V $\delta 1$ reactivity to CMV. Another possibility 
is that the absence of cross-reactivity is due to co-recognition of the cell lineage/tissue origin, which is different for CMV and KSV if one considers the major site of latency. BTN isoforms and multimers are good candidate molecules which could possibly confer tissue specificity after co-recognition [10,189].

The possible cross-reactivity between HHV-1/2-reactive and EBV-reactive $\gamma \delta$ is another open question. V $\delta 2$ cells are possibly targeted in both contexts, and PhAg-reactive cells are involved in both cases. To our knowledge, an analysis of possible cross-reactivity of V $\delta 2$ cells against cells infected by these viruses is not reported.

\section{1. $\gamma \delta$ in HIV Infections}

The effects of HIV on $\gamma \delta$ have been reviewed recently [190,191]. Along with CD4 depletion, numbers of $\mathrm{V} \gamma 9 \mathrm{~V} \delta 2$ in blood are severely decreased at the early phase of HIV infection, leading to an inverted $\mathrm{V} \delta 2^{\text {pos }} / \mathrm{V} \delta 2^{\text {neg }}$ ratio. This may precede inversion of the CD4/CD8 ratio [192]. Importantly, V82 depletion correlates with HIV load and CD4 depletion [193]: it is reversed by antiretroviral therapy (ART), at least partially, and V 22 cells are lost again in patients following the interruption of treatment [194,195]. The cells responsive to PhAgs (characterised by $\mathrm{V} \gamma$ 9-JP usage and characteristic CDR3 sequences) are preferentially depleted, and the remaining $\mathrm{V} \gamma 9 \mathrm{~V} \delta 2$ cells have been found to be hyporesponsive to PhAgs. Interestingly, a rapid decline in V $\gamma 9 \mathrm{~V} \delta 2 \mathrm{~T}$ cells is also observed following SIV infection of macaques, and is preceded by a transient expansion, suggesting activation. In line with this, a specific in vitro activation of $\mathrm{V} \gamma 9 \mathrm{~V} \delta 2$ cell lines derived from healthy subjects against HIV-infected targets has been observed [16], and PhAgactivated cell lines can kill HIV-infected targets [196]. V82 are preserved in blood in HIV elite controllers (ECs, also called natural viral suppressors) [197]. However, TCR $\gamma$ repertoire analysis revealed that they have a lower proportion of $\mathrm{V} \gamma$ 9-JP rearrangements corresponding to PhAg-responsive cells [198]. It is not clear, however, if this feature is due to HIV carriage or if most ECs belong to the subtype of individuals with naturally weak $\mathrm{PhAg}$ responses mentioned above $[62,119,120]$. Although the cause of V $\delta 2$ cell depletion in progressors is not clear, several mechanisms have been identified which can contribute to it (see [191] for a review). As mentioned above, HHV-6 infection can promote HIV infection of V82 cells [161-164].

Paralleling V $\delta 2$ depletion, a persistent increase in V $\delta 1 \mathrm{~T}$ cells occurs in the blood of HIV-viraemic patients, and may start prior to seroconversion $[199,200]$. This is also observed in SIV-infected macaques [201]. Repertoire analysis of V $\delta 2^{\text {neg }}$ cells in HIV patients did not show clear differences with healthy controls, arguing for an unbiased polyclonal or oligoclonal amplification [202,203]. Indirect observations suggest that V $\delta 1$ amplification is not a direct effect of HIV infection: V $\delta 1$ amplification does not correlate with HIV load; in contrast to V 82 depletion, it occurs in ECs, although to a lesser extent, and is not reversed by ART $[197,204]$; and high V $82^{\text {neg }}$ counts in some ECs do not correlate with the presence of HIV in blood, but parallel increased HIV replication in gut [204].

Several factors possibly contributing to V $\delta 1$ expansion have been identified. (a) A stimulation by opportunistic pathogens is possible, as the highest V $\delta 1$ counts were observed in the context of co-infection by Candida albicans [205]; in vitro, V $\delta 1$ expanded from HIV patients responded to Candida albicans [206] and Mycobacterium avium [207]. (b) An increase in V $\delta 1$ is observed in the gut and reproductive tract where HIV replication occurs [194,208,209], also supported by observations in the macaque model [201,210]; the increase in blood V $\delta 1$ cells may thus result from a mobilisation from the gut or tissues, possibly favoured by an alteration of the epithelial homeostasis [204,206,208]. A systemic release of HIV-tat peptide could also interfere with V $\delta 1$ chemotaxis towards tissues [211].

\section{HIV-HHV Co-Infections}

Most HIV patients carry HHVs subclinically. One study followed viral shedding in semen by HIV-infected men who have sex with men (MSM), in a 48-week follow-up. HHV secretion was found in $94 \%$ of cases, with the following percentages for different viruses: 
85\% (CMV), 81\%(EBV), 35\% (HHV-7), 29\% (HHV-6) and 26\% (HSVs) [212]. CMV was found in vaginal secretion in $78 \%$ of HIV-infected women in Uganda in a similar time window [213]. Considering the frequency of HHV carriage in the HIV-infected population, it is extremely difficult to dissociate the effects of HIV from those of CMV. In murine LCMV infection, viral reactivation occurs mainly in tissues, and the reactivation of HHV is thus presumably underestimated in human studies where viral infection/reactivation is assessed in blood [214]. Individuals carrying HSV-1/2 display an increased risk of acquiring HIV, possibly because HSV infection induces epithelial lesions favouring HIV entry [215-217]. The prominent effect of CMV on NK cells in the course of HIV infections is well-documented and provides evidence for HIV-CMV interaction. CMV infection results in a dramatic change of the expression of NKG2A/C HLA-E-binding receptors on NK cells. NKG2A is an inhibitory receptor expressed on early differentiated NK cells, whereas NKG2C is activatory and expressed on terminally differentiated memory-like NK cells [167]. During CMV infection NKG2C ${ }^{+} \mathrm{NK}$ cells expand while NKG2A ${ }^{+} \mathrm{NK}_{\text {cells }}$ are lost in transplant patients, but also in healthy $\mathrm{CMV}^{+}$children [218-220]. A similar change was observed in HIV patients, possibly driven by the reactivation of CMV as it does not correlate with HIV virus load and persists on ART [221-223]. Moreover, when comparing HIV patients and controls, the difference in NKG2A/C frequencies disappears when patients are stratified for CMV [224]. In comparison, EBV and HSV-2 do not promote NKG2C ${ }^{+} \mathrm{NK}$ cell expansion [225,226]. NKG2A/C receptors are also expressed on V $\delta 1$ and $\mathrm{V} \delta 2$ cells [227]. In the blood of HIV-viraemic patients the proportion of $\mathrm{NKG}^{2} \mathrm{~A}^{+} \mathrm{V} \delta 1$ cells decreases, while NKG2 $\mathrm{C}^{+} \mathrm{V} \delta 1$ cells increase in number and display higher cytolytic activity on HLA-E-expressing targets [208,214,228]. Data concerning the role of CMV in NKG2C upregulation on $\gamma \delta$ cells in the absence of HIV are still unclear. In kidney transplant patients, although $C M V^{p o s}$ patients had mainly NKG2A ${ }^{\text {neg }} \mathrm{V} \delta 1$ cells, this was also the case in control CMV neg transplant patients [91,229]; in CMV-infected newborns, increased levels of both NKG2A and C were observed on $\gamma \delta$ T cells [98]; and in Ugandan children, a progressive increase in NKG2C+ cells was observed in infants infected by CMV during the first years of life [76]. Thus, by analogy with NK cells, it is tempting to speculate that V $\delta 1$ expansion in HIV infection is linked to CMV infection.

The effect of CMV in HIV infection seems detrimental, as CMV-seronegative individuals recover better after ART [230]. In longitudinal studies of co-infected patients, intermittent CMV /EBV replication in blood is associated with increased HIV-DNA [231]. CMV may also contribute to the V $\delta 2$ decline in HIV patients as V $\delta 2$ counts correlate negatively with the reactivation of CMV, reflected by high CMV-DNA and anti-CMV antibodies [232]. However, in one study, a high NKG2C/NKG2A ratio on NK cells was a marker of slower progression of HIV disease and higher CD4 counts two years after primary HIV infection [233]. In another report [234], patients with high NKG2C on NK cells showed lower HIV-RNA at one month under ART; no CMV reactivation was detected, but all patients were seropositive for CMV and it was suggested that pre-existing CMV immunity was beneficial for recovery. Assuming that a high NKG2C/NKG2A ratio on NK cells reflects mainly CMV infection, CMV carriage would appear beneficial; this was attributed to NK cell activity in both studies, but a role of V $\delta 1$ cells is an alternative non-exclusive possibility.

\section{CMV and HBV/HCV}

$\gamma \delta \mathrm{T}$ cells are enriched in liver tissue compared to peripheral blood [235-237], with increased proportions of V $\delta 2^{\text {neg }}$ cells. V $\delta 3$ cells, which are almost absent in blood, represent a significant population in liver. Whereas one study reported the predominance of V $\delta 2$ cells [236], another recent study shows that V $\delta 1$ cells represent a major liver subset [237]. In a population of patients with chronic liver disease but no history of HBV/HCV infection, as well as healthy controls, phenotype determination and repertoire analysis by NGS showed that the liver contains a population of liver-resident CD27lo $/ C D 45 R A^{\text {hi }} / \mathrm{V} \delta 2^{\text {neg }}$ cells $\left(\mathrm{V} \delta 1^{+}\right.$or $\mathrm{V} \delta 3^{+}$) which express the markers of tissue-resident CD69, CXCR3 and CXCR6, 
which are absent from blood. These cells represent liver-restricted clonotypes, and are possibly involved in liver tissue immunosurveillance [237]. A second CD27lo /CD45RA ${ }^{\text {lo }}$ population contains highly expanded clonotypes which are present in blood, and thus circulate between both compartments. Very little sharing of clonotypes between donors was observed, and most sequences were essentially private [237].

Hepatitis B and C viruses (HBV, HBC) infect approximately 250 and 70 million persons worldwide, respectively, and are known to provoke liver cirrhosis, liver failure and hepatocellular carcinoma. HBV infection is cleared in $95 \%$ of healthy adults. In contrast, 60 to $80 \%$ of HCV-infected patients progress toward a chronic liver disease (see $[238,239]$ for recent reviews). Most available data on $\gamma \delta \mathrm{T}$ cells in $\mathrm{HBV} / \mathrm{HCV}$ infections concern chronic infections.

An increase in blood $\gamma \delta$ cells occurs in chronic HCV patients $[83,240,241]$, but also in non-viral chronic liver diseases [242]. The frequency of V $\delta 1$ cells in the liver of HCV and HCV-HIV patients correlates positively with inflammation and necrosis in liver tissue; V 81 cells also display an activated phenotype $\left(\mathrm{CD} 62 \mathrm{~L}^{\text {neg }} \mathrm{CD} 45 \mathrm{RO}^{\mathrm{pos}}\right)$. Spectratyping of the V $\delta 1$ TCR CDR3 regions of liver-infiltrating cells did not reveal oligoclonality [243,244]. A certain level of oligoclonality of blood $\gamma \delta$ cells from HCV patients was revealed by NGS-based repertoire analysis, but repertoire complexity was similar in patients and controls. A more frequent expansion of $\mathrm{V} \delta 3$ clones was noticed in $\mathrm{HCV}$ patients, but their reactivity toward $\mathrm{HCV}$ could not be ascertained. The repertoire was also not significantly changed after treatment with direct-acting antiviral drugs [245]. These results suggest that alterations of the $\mathrm{V} \delta 2^{\text {neg }}$ compartment may not be specifically due to HCV infection, and it has been suggested that it may rather reflect a homeostatic response to liver inflammation [244].

The V $\delta 2$ cell compartment may also be altered in chronic HCV patients. Two studies indicate a decreased percentage and count of V $\delta 2$ cells in blood [246,247]. The remaining cells expressed activation markers, including CD107, but were found to display a decreased expression of perforin compared to controls [246]. A reduced frequency of effector memory phenotype is observed in blood and reversed in patients with a sustained response to antiviral therapy, suggesting that differentiated effectors are recruited in tissue sites of viral replication. In vitro, ABP-activated V $\delta 2$ cells from healthy donors displayed IFN $\gamma$ dependent antiviral activity against an HCV-infected Huh7 cell line, but the receptors involved were not determined [247].

During HBV infection, $\gamma \delta \mathrm{T}$ cell subsets frequencies are not dramatically altered in blood. Increased levels of both V $\delta 2$ and $V \delta 2^{\text {neg }}$ subsets are reported in asymptomatic HBV carriers compared to healthy controls [248]. In a study by Chang et al., acute HBV infection was associated with increased Th1 markers on V $\delta 1$ cells, whereas a chronic status was associated with increased Th1 markers on V 82 cells [249]. In chronic HBV infection, elevated or decreased percentages of $\gamma \delta$ cells in blood have been reported, possibly due to the inclusion or not of patients with advanced disease [250,251] or to genetic factors [249]. A decrease in V $\delta 2$ cells in blood during episodes of exacerbation of liver disease is also reported, with the remaining cells showing increased activation markers, increased cytolytic activity [248,250,252], high production of TNF as well as IL-17 and a variable ability to produce IFN $\gamma$ upon in vitro stimulation; their ability to produce TNF, correlated with low hepatic cytolysis, suggests a role in liver tissue protection [252].

In $\mathrm{HCV}^{+}$or $\mathrm{HBV}^{+}$liver transplant patients, the predominance of the $\mathrm{V} \delta 1$ subset in blood $\gamma \delta \mathrm{T}$ cells has been observed in $\mathrm{CMV}^{+}$but not $\mathrm{EBV}^{+}$patients (on a serologic status basis) [83]. In $\mathrm{HCV}^{+}$patients $\mathrm{V} \delta 1$ cells displayed mostly a terminally differentiated phenotype, as reported in persistent CMV infections. However, a link with CMV carriage was also seen in immunocompetent patients, in whom the presence of CMV-DNA has been examined in liver tissue by PCR. CMV infection of the liver was frequent in $\mathrm{HBV}^{+}(52 \%)$ and $\mathrm{HCV}^{+}(36 \%)$ patients. Interestingly, the presence of CMV-DNA correlated differently with liver damage in $\mathrm{HCV}^{+}$or $\mathrm{HBV}^{+}$livers, estimated from ALT and bilirubin levels: while CMV-DNA was associated with decreased ALT and bilirubin in the case of HBV, the reverse was observed in $\mathrm{HCV}$ patients, arguing for a detrimental effect of CMV in $\mathrm{HCV}$ 
infection, but not in the case of HBV [253]. Thus, CMV is likely a driver of the V $\delta 1$ increase in $\mathrm{HCV} / \mathrm{HBV}$ infections in an immunosuppressed context, and the outcome may depend on the viral co-infection context.

As with HIV infections, NK responses provide evidence that CMV modulates the responses to $\mathrm{HBV} / \mathrm{HCV}$. In co-infections, CMV seropositivity determines the expansion of highly differentiated NK cells expressing NKG2C and cytotoxic markers, and is not associated with adverse clinical outcomes, suggesting a role in limiting immunopathology [254].

\section{CMV and HEV}

$\mathrm{HEV}$ infection is usually benign and asymptomatic, and the infection is naturally cleared in immunocompetent individuals. It becomes a concern in the context of solid organ transplantation, as about 2/3 of patients progress towards chronic infection [255]. Our group has analysed the phenotype and frequency of $\gamma \delta \mathrm{T}$ cells in a panel of rare immunocompetent patients with acute symptomatic infections [256]; we found an elevated frequency of $V \delta 2^{\text {neg }}$ cells compared to age- and sex-matched healthy controls. Segregation of patients and controls according to CMV serology revealed that high V $\delta 1$ frequency was associated with combined HEV infection and CMV seropositivity. Again, high V $\delta 1$ levels were associated with a higher proportion of V $\delta 1$ cells with a TEMRA phenotype. In vitro, $\gamma \delta \mathrm{T}$ cells from patients were found to upregulate CD69 activation markers when stimulated with HEV-infected hepatocarcinoma cells, and this was selective for CMV carriers. This concerned $V \delta 2^{\text {neg }}$ and $V \delta 2^{\text {pos }}$ cells, although the response of the two subsets correlated negatively. HEV infection in CMV carriers was also associated with an increased concentration of IL-10 in the serum. This indicates that CMV carriage is determinant for the expansion of $V \delta 2^{\text {neg }}$ cells, although both $V \delta 2^{\text {neg }}$ and $V \delta 2^{\text {pos }}$ subsets may be involved in the response to HEV. The data also suggest a possible role in limiting immunopathology through IL-10 production by uncharacterised cells. HEV-infected hepatocarcinoma cells also induce the upregulation of IL-10 production by co-cultivated $\gamma \delta$ cells, suggesting alternatively that this production could provide an immune escape mechanism for HEV by dampening the activity of antiviral effectors. Strikingly, a skewing of V $\delta 2^{\text {pos }} / \mathrm{V} \delta 2^{\text {neg }}$ proportions was not observed in immunosuppressed transplant patients at the acute or chronic phase [11]. Nevertheless, a depletion of more differentiated V82 ${ }^{\text {pos }}\left(\mathrm{CD}^{-} 7^{-} \mathrm{CD}^{-} 5 \mathrm{RA}^{-}\right)$and $\mathrm{V} \delta 2^{\text {neg }}$ cells (TEMRA, CD27 ${ }^{-} \mathrm{CD} 4 \mathrm{RA}^{+}$) was observed, suggesting their recruitment in tissues, as reported in the case of chronic HCV patients [247].

\section{Is There a Role for HHVs in Other Viral Co-Infections?}

The mobilisation of $\gamma \delta$ subsets in acute viral infections in humans and animal models has been extensively reviewed, and we will discuss here the findings relevant to HHV co-infection and cross-protection conferred by different microbes [16,17,257].

Following influenza virus infection in mice (reviewed in [17]), successive waves of $\gamma \delta \mathrm{T}$ cell infiltration have been detected in the lung, with a first wave of pro-inflammatory $\mathrm{V} \gamma 4$ cells followed by infiltration of $\mathrm{V} \gamma 2$ and $\mathrm{V} \gamma 1.1 \mathrm{~T}$ cells, which are thought to control inflammation [258]. In humans, although no massive mobilisation is reported in the periphery during influenza A/B infections (IAV/IBV), IL-17-producing V $\gamma 9 \mathrm{~V} \delta 2$ cells are increased in the bronchial lavage fluid of infected patients, and this correlates with lower pneumonia severity [258]. Ex vivo, blood V $\delta 2$ cells from patients produce IFN $\gamma$ upon stimulation by IBV-infected cells. Responding cells present the TCR characteristics of PhAg-responsive cells and kill IBV-infected cells in a PhAg-dependent manner [61,259]. Since influenza infections are frequent and recurrent across a lifespan, they may participate in the shaping of the $\gamma \delta$ T cell repertoire after birth [61]. Nevertheless, the reactivation of HSV, CMV and EBV is frequent in ICU patients treated for severe influenza infections, and are associated with high morbidity and mortality [260]. Influenza virus infection increases the titre of antibodies against EBV, also indicative of the reactivation of EBV, and this is also observed with the measles virus and adenovirus [261]. Thus, the interplay 
between these viruses and the possibility of cross-immunity/cross-reactivity deserves further investigation.

The contribution of HHV carriage is also questionable in the context of SARS-CoV and SARS-Cov-2 infections. These viruses cause an acute respiratory infection of variable severity, and $\mathrm{V} \gamma 9 \mathrm{~V} \delta 2 \mathrm{~T}$ cells are mobilised in both cases [262,263]. In SARS-CoV patients, an expansion of this subset was observed at a distance from the initiation of the disease ( $\sim 3$ months), and expanding cells were able to kill in-vitro-infected targets. In SARS$\mathrm{CoV}-2$ patients, an early depletion of the $\mathrm{V} \delta 2$ subset was reported, with a possible slight increase in $\mathrm{V} \delta 2^{\text {neg }} \mathrm{V} \delta 1^{\text {neg }} \gamma \delta$ cells. Remaining $\mathrm{V} \delta 2$ cells displayed markers of activation, suggesting activation and traffic to the lung, similar to what was observed in influenza infection in mice. Again, the reactivation of EBV in severe COVID-19 disease is a factor of morbidity and complications, but the reactivation of other HSVs can also affect the course of disease $[35,264-268]$. How this affects $\gamma \delta \mathrm{T}$ cells and their putative protective or deleterious activity is unknown.

\section{HHVs in Malaria}

Alterations of $\gamma \delta$ subsets in malaria have been reviewed recently [269-271]. In highly endemic areas, chronic plasmodium infection leads to V $\delta 2$ depletion in peripheral blood, while remaining cells present exhaustion markers and reduced functionality, suggestive of chronic stimulation [272-275]. Conversely, V82 cells expand in primo-infected people from non-endemic areas. The highest expansion was observed at the recovery phase [276], a delay which is unexplained and may be linked to a peak of production of malarial antigens or to a role of $\mathrm{V} \delta 2$ cells in the resolution of infection. In vitro, $\mathrm{V} \gamma 9 \mathrm{~V} \delta 2 \mathrm{~T}$ cells are stimulated by Plasmodium falciparum (Pf)-infected erythrocytes, and this is due to $\mathrm{PhAg}$ production by parasites which carry the non-mevalonate pathway of $\mathrm{PhAg}$ synthesis. $\mathrm{PhAg}$ can be released from infected erythrocytes and stimulate V $\delta 2$ cells after capture by other cells $[277,278]$. It was recently shown that infected erythrocytes express BTN3A1 and directly stimulate granulysin-dependent parasite killing by V $\gamma 9 \mathrm{~V} \delta 2 \mathrm{~T}$ cells $[279,280]$.

In highly endemic areas, the main observable perturbation in the $\gamma \delta \mathrm{T}$ cell compartment is an expansion of V $81 \mathrm{~T}$ cells displaying resting (CD69-DR-), a TEMRA phenotype $\left(\mathrm{CD} 45 \mathrm{RA}^{+}\right)$and frequent expression of CD8. V $\delta 1$ cells in malaria thus partly phenocopy V $\delta 2^{\text {neg }} \gamma \delta$ T cells that expand during CMV expansions [270,281,282]. Nevertheless, CDR3 $\delta$ spectratyping indicated that V $\delta 1$ expansion in chronically infected children was highly polyclonal or displayed a level of clonal focussing, similar to the one observed in healthy children from the same endemic area [281]. In a cohort of stable infected people living in highly endemic Laos, V $\delta 2^{\text {neg }}$ cells proliferated in vitro against crude Pf antigens in the presence of IL-2, produced IFN $\gamma$ as well as IL-10 and were associated with high concentrations of IL-10 in plasma, suggesting anti-inflammatory potential and a role in the control of chronic inflammation. V81 cells from infected donors also expanded and secreted IL-10 in the absence of Pf antigens when IL-2 was present, presumably primed, in vivo, by an unknown stimulus [283].

The reactivation of latent HHVs is frequent during malaria, and the reactivation of EBV is probably linked to the high incidence of Burkitt's lymphoma in highly endemic areas [284-286]. An exhaustive study of the reactivation of HHV has been conducted in Ugandan children with malaria via the detection of viral DNA in plasma and saliva. All children had at least one HHV detected in saliva, most frequently HHV-6/7 (70\%) and CMV (50\%). The CIDR $1 \alpha$ domain of Pf membrane protein 1 is a strong polyclonal B cell activator, possibly causing the reactivation of EBV [287]. Viral DNA was strongly diminished by antimalarial treatment, at least concerning HSV-1 or EBV, indicative of a direct link with Pf infection $[288,289]$. Thus, the reactivation of HHV could presumably explain V $\delta 1$ expansions in Plasmodium infections in highly endemic areas, but this requires formal demonstration. This is not detrimental, as high V $\delta 1$ frequencies are associated with a tolerant or stable immune status among malaria-exposed individuals [283,290,291]. 


\section{Lessons from Mycobacterial Infections}

The outgrowth of $\mathrm{V} \gamma 9 \mathrm{~V} \delta 2 \mathrm{~T}$ cells has been observed, in vivo, in multiple bacterial infections. Bacterial extracts from mycobacteria, but also from Gram-positive and Gram-negative bacteria, promote $\mathrm{V} \gamma 9 \mathrm{~V} \delta 2 \mathrm{~T}$ cell expansions. This finding led to the first identification of PhAgs from mycobacteria that produce HMBPP through the DOXP pathway [292,293]. $\mathrm{V} \gamma 9 \mathrm{~V} \delta 2 \mathrm{~T}$ cells provide some protection against mycobacterial and other infections, such as HMBPP-producing Listeria monocytogenes, in a simian model in particular (reviewed by Shen et al. [294]). Mycobacterium bovis BCG also produces PhAgs, leading to the expansion of $\mathrm{V} \gamma 9 \mathrm{~V} \delta 2$ in vivo after infection in macaques, although this was not apparent in infants [295,296]. V $\gamma 9 \mathrm{~V} \delta 2$ cells can kill intracellular bacteria through a granulysin- and perforin-dependent process [297]. It seems, however, that only a subset of PhAg-reactive V $\gamma 9 \mathrm{~V} \delta 2$ cells are activated by BCG-infected dendritic cells [298]. Effects independent of the TCR/BTN3A axis are, however, possible, since $\gamma \delta$ cell expansion following PhAg administration also occurred in pigs [299].

Similar to HHVs, M. tuberculosis and BCG infections lead to a state of asymptomatic latency in most individuals. Latency can last at least for 16 months and possibly for life, promoting sustained protective immunity. They can also reactivate from this state following immune depression and other favourable conditions [300-302].

BCG vaccination has been shown to provide protection against multiple unrelated infections, and reduces mortality in vaccinated infants far beyond its effects on tuberculosis [303]. Protection by BCG vaccination is reported toward respiratory viral infections and genital warts caused by HPV (reviewed in [304]). It reduces SARS-Cov2 infection severity [305-307] and improves the responses to other vaccines in humans (IAV, HBV). Remarkably, BCG vaccination is reported to reduce the reactivation of HSV infections in two clinical trials involving 15 and 109 patients, thus reducing the recurrence of genital herpes lesions [308,309]. This is in line with both infections being targeted by V $\gamma 9 \mathrm{~V} \delta 2$ cells, and suggests a possible protective role of memory $\mathrm{V} \gamma 9 \mathrm{~V} \delta 2 \mathrm{~T}$ cells through PhAg sensing. Nevertheless, this view is challenged by reports that BCG vaccination also protects mice against IAV and HSV-2 infection, in addition to multiple other viral infections. In humans, vaccination increases, in vitro, the production of IFN $\gamma$ from lymphoid cells stimulated with unrelated microbial antigens such as tetanus toxoid, LPS, Candida albicans, Staphylococcus aureus or HBV [310]. Therefore, protection may also rely on unspecific mechanisms independent of $\mathrm{V} \gamma 9 \mathrm{~V} \delta 2$ cells and PhAg sensing [304], or possibly on CD4 or CD8 T cells specific to non-targeted antigens [311].

\section{Discussion and Concluding Remarks}

V $\gamma 9$ V 82 PhAg-responsive cells display innate-like properties and react and/or expand in multiple infectious contexts, including EBV, HHV1/2, HHV6, influenza and plasmodium infections. PhAg sensing is a common determinant of this activity, and raises questions about the real function of PhAgs. A straightforward hypothesis is that endogenous IPP is the primary stimulus promoting $\mathrm{V} \gamma 9 \mathrm{~V} \delta 2$ expansion, helped by costimulatory pathways such as NK receptors, CD16, PRRs and innate cytokines. If this is the case, and considering persistence of memory cells, $\mathrm{V} \gamma 9 \mathrm{~V} \delta 2$ would be expected to cross-react in different contexts and to confer broad cross-protection. Such a model would at least partly explain the effect of BCG, and extend the concept of cross-protection described by Barton et al. in mice infected with murine herpes viruses $\gamma \mathrm{HV}-68$ or mCMV [312], relating to conventional T cells. The model would also fit with the broad polyclonal $\mathrm{V} \gamma 9 \mathrm{~V} \delta 2$ repertoire of influenzareactive/PhAg-reactive cells [61]. Alternatively, ubiquitous IPP could serve to promote the proper expression of BTN family multimers. These possibly promote the cell surface expression of uncharacterised clonotypic ligands which could be either tissue- or pathogenrelated markers of cellular stress. IPP could be viewed as a positive selection driver, possibly used also during thymic differentiation. In this case, the whole compartment would appear globally PhAg-reactive in experimental conditions (high IPP or HMBPP concentration), but individual clones would be more selective for a clonotypic ligand. 
This would explain why mycobacteria-reactive $\mathrm{V} \gamma 9 \mathrm{~V} \delta 2$ cells represent only a subset of PhAg-reactive cells [298], but would also limit the possibility for cross-immunity.

In the human V $\delta 2^{\text {neg }}$ compartment, an adaptive-like behaviour is supported by the occurrence of massive, oligoclonal and essentially private expansions arising after birth upon encountering a pathogen. Available data suggest that a significant, although difficult to evaluate, fraction of these cells is mobilised by CMV infection; at present, there is no evidence that this virus promotes possible cross-protection or cross-immunity toward other pathogens. This is somewhat striking as no CMV antigen has been found to be a TCR ligand. One can hypothesise that this virus induces a permissive signal or determinant allowing for the recognition of stress markers recognised in a clonal fashion, as is the case for EPCR or EpHA2.

In future research it might thus be important to evaluate the cross-reactivity of $\gamma \delta$ cells toward different pathogens which preferentially target one or the other of the V $\delta 2$ or non-V $\delta 2$ compartments. Indeed, there are accumulating indications that non-V $\delta 2$ cells are mobilised selectively in CMV carriers in hepatitis B/C/E or HIV infections, but at present it is not clear if the mobilised cells effectively participate in the anti-hepatitis virus/HIV response (with a possible involvement of a permissive determinant from CMV) or if they exclusively respond to CMV. It will be important to study whether different HHVs induce or modulate alternative $\gamma \delta$ responses and whether these are beneficial or not to the host, with the ultimate goal to determine whether HHVs should be considered symbiotic microbes.

Author Contributions: Conceptualisation, F.M. and E.C.; methodology, E.C.; writing-original draft preparation, F.M. and E.C.; writing-review and editing, F.M. and E.C.; funding acquisition, E.C. All authors have read and agreed to the published version of the manuscript.

Funding: This work was funded by ANRS, grant number ECTZ103203. F.M. is supported by a fellowship from ANRS, grant number ECTZ103206.

Institutional Review Board Statement: Not applicable.

Informed Consent Statement: Not applicable.

Conflicts of Interest: The authors declare no conflict of interest.

\section{References}

1. Wertheim, J.O.; Smith, M.D.; Smith, D.M.; Scheffler, K.; Kosakovsky Pond, S.L. Evolutionary origins of human herpes simplex viruses 1 and 2. Mol. Biol. Evol. 2014, 31, 2356-2364. [CrossRef] [PubMed]

2. Arvin, A.; Abendroth, A. VZV: Immunobiology and host response. In Human Herpesviruses: Biology, Therapy, and Immunoprophylaxis; Arvin, A., Campadelli-Fiume, G., Mocarski, E., Moore, P.S., Roizman, B., Whitley, R., Yamanishi, K., Eds.; University Press: Cambridge, UK, 2007.

3. Schmiedel, D.; Mandelboim, O. Disarming Cellular Alarm Systems-Manipulation of Stress-Induced NKG2D Ligands by Human Herpesviruses. Front. Immunol. 2017, 8, 390. [CrossRef]

4. Crough, T.; Khanna, R. Immunobiology of human cytomegalovirus: From bench to bedside. Clin. Microbiol. Rev. 2009, 22, 76-98. [CrossRef] [PubMed]

5. Sehrawat, S.; Kumar, D.; Rouse, B.T. Herpesviruses: Harmonious Pathogens but Relevant Cofactors in Other Diseases? Front. Cell Infect. Microbiol. 2018, 8, 177. [CrossRef]

6. Khairallah, C.; Dechanet-Merville, J.; Capone, M. Gammadelta T Cell-Mediated Immunity to Cytomegalovirus Infection. Front. Immunol. 2017, 8, 105. [CrossRef] [PubMed]

7. Krmpotic, A.; Podlech, J.; Reddehase, M.J.; Britt, W.J.; Jonjic, S. Role of antibodies in confining cytomegalovirus after reactivation from latency: Three decades' resume. Med. Microbiol. Immunol. 2019, 208, 415-429. [CrossRef]

8. Sylwester, A.W.; Mitchell, B.L.; Edgar, J.B.; Taormina, C.; Pelte, C.; Ruchti, F.; Sleath, P.R.; Grabstein, K.H.; Hosken, N.A.; Kern, F.; et al. Broadly targeted human cytomegalovirus-specific $\mathrm{CD}^{+}$and $\mathrm{CD} 8^{+} \mathrm{T}$ cells dominate the memory compartments of exposed subjects. J. Exp. Med. 2005, 202, 673-685. [CrossRef]

9. Vantourout, P.; Hayday, A. Six-of-the-best: Unique contributions of gammadelta T cells to immunology. Nat. Rev. Immunol. 2013, 13, 88-100. [CrossRef]

10. Hayday, A.C. Gammadelta T Cell Update: Adaptate Orchestrators of Immune Surveillance. J. Immunol. 2019, $203,311-320$. [CrossRef] 
11. Abravanel, F.; Barrague, H.; Dorr, G.; Saune, K.; Peron, J.M.; Alric, L.; Kamar, N.; Izopet, J.; Champagne, E. Conventional and innate lymphocytes response at the acute phase of HEV infection in transplanted patients. J. Infect. 2016, 72, 723-730. [CrossRef]

12. Papadopoulou, M.; Sanchez Sanchez, G.; Vermijlen, D. Innate and adaptive gammadelta T cells: How, when, and why. Immunol. Rev. 2020, 298, 99-116. [CrossRef] [PubMed]

13. Patel, S.J.; Zhao, G.; Penna, V.R.; Park, E.; Lauron, E.J.; Harvey, I.B.; Beatty, W.L.; Plougastel-Douglas, B.; Poursine-Laurent, J.; Fremont, D.H.; et al. A Murine Herpesvirus Closely Related to Ubiquitous Human Herpesviruses Causes T-Cell Depletion. J. Virol. 2017, 91, e02463-16. [CrossRef] [PubMed]

14. Blackman, M.A.; Flano, E. Persistent gamma-herpesvirus infections: What can we learn from an experimental mouse model? J. Exp. Med. 2002, 195, F29-F32. [CrossRef] [PubMed]

15. Flano, E.; Woodland, D.L.; Blackman, M.A. A mouse model for infectious mononucleosis. Immunol. Res. 2002, 25, 201-217. [CrossRef] [PubMed]

16. Poccia, F.; Agrati, C.; Martini, F.; Capobianchi, M.R.; Wallace, M.; Malkovsky, M. Antiviral reactivities of gammadelta T cells. Microbes Infect. 2005, 7, 518-528. [CrossRef]

17. Sabbaghi, A.; Miri, S.M.; Keshavarz, M.; Mahooti, M.; Zebardast, A.; Ghaemi, A. Role of gammadelta T cells in controlling viral infections with a focus on influenza virus: Implications for designing novel therapeutic approaches. Virol. J. 2020, 17, 174. [CrossRef]

18. Zhao, Y.; Lin, L.; Xiao, Z.; Li, M.; Wu, X.; Li, W.; Li, X.; Zhao, Q.; Wu, Y.; Zhang, H.; et al. Protective Role of gammadelta T Cells in Different Pathogen Infections and Its Potential Clinical Application. J. Immunol. Res. 2018, 2018, 5081634. [CrossRef]

19. Lieberman, P.M. Epigenetics and Genetics of Viral Latency. Cell Host Microbe 2016, 19, 619-628. [CrossRef] [PubMed]

20. Soderberg-Naucler, C.; Fish, K.N.; Nelson, J.A. Interferon-gamma and tumor necrosis factor-alpha specifically induce formation of cytomegalovirus-permissive monocyte-derived macrophages that are refractory to the antiviral activity of these cytokines. $J$. Clin. Investig. 1997, 100, 3154-3163. [CrossRef]

21. Wills, M.R.; Poole, E.; Lau, B.; Krishna, B.; Sinclair, J.H. The immunology of human cytomegalovirus latency: Could latent infection be cleared by novel immunotherapeutic strategies? Cell Mol. Immunol. 2015, 12, 128-138. [CrossRef]

22. Van Damme, E.; Sauviller, S.; Lau, B.; Kesteleyn, B.; Griffiths, P.; Burroughs, A.; Emery, V.; Sinclair, J.; Van Loock, M. Glucocorticosteroids trigger reactivation of human cytomegalovirus from latently infected myeloid cells and increase the risk for HCMV infection in D+R+ liver transplant patients. J. Gen. Virol. 2015, 96, 131-143. [CrossRef]

23. Harrison, K.S.; Zhu, L.; Thunuguntla, P.; Jones, C. Antagonizing the Glucocorticoid Receptor Impairs Explant-Induced Reactivation in Mice Latently Infected with Herpes Simplex Virus 1. J. Virol. 2019, 93, e00418-19. [CrossRef]

24. Helantera, I.; Kyllonen, L.; Lautenschlager, I.; Salmela, K.; Koskinen, P. Primary CMV infections are common in kidney transplant recipients after 6 months valganciclovir prophylaxis. Am. J. Transplant. 2010, 10, 2026-2032. [CrossRef] [PubMed]

25. Couzi, L.; Helou, S.; Bachelet, T.; Moreau, K.; Martin, S.; Morel, D.; Lafon, M.E.; Boyer, B.; Alain, S.; Garrigue, I.; et al. High incidence of anticytomegalovirus drug resistance among D+R- kidney transplant recipients receiving preemptive therapy. Am. J. Transplant. 2012, 12, 202-209. [CrossRef]

26. Patel, R.; Paya, C.V. Infections in solid-organ transplant recipients. Clin. Microbiol Rev. 1997, 10, 86-124. [CrossRef] [PubMed]

27. Weikert, B.C.; Blumberg, E.A. Viral infection after renal transplantation: Surveillance and management. Clin. J. Am. Soc. Nephrol. 2008, 3 (Suppl. 2), S76-S86. [CrossRef]

28. Hill, J.A.; Mayer, B.T.; Xie, H.; Leisenring, W.M.; Huang, M.L.; Stevens-Ayers, T.; Milano, F.; Delaney, C.; Sorror, M.L.; Sandmaier, B.M.; et al. The cumulative burden of double-stranded DNA virus detection after allogeneic HCT is associated with increased mortality. Blood 2017, 129, 2316-2325. [CrossRef] [PubMed]

29. Handous, I.; Achour, B.; Marzouk, M.; Rouis, S.; Hazgui, O.; Brini, I.; Khelif, A.; Hannachi, N.; Boukadida, J. Co-infections of human herpesviruses (CMV, HHV-6, HHV-7 and EBV) in non-transplant acute leukemia patients undergoing chemotherapy. Virol. J. 2020, 17, 37. [CrossRef]

30. Sanchez-Ponce, Y.; Varela-Fascinetto, G.; Romo-Vazquez, J.C.; Lopez-Martinez, B.; Sanchez-Huerta, J.L.; Parra-Ortega, I.; FuentesPanana, E.M.; Morales-Sanchez, A. Simultaneous Detection of Beta and Gamma Human Herpesviruses by Multiplex qPCR Reveals Simple Infection and Coinfection Episodes Increasing Risk for Graft Rejection in Solid Organ Transplantation. Viruses 2018, 10, 730. [CrossRef]

31. Zhou, J.R.; Shi, D.Y.; Wei, R.; Wang, Y.; Yan, C.H.; Zhang, X.H.; Xu, L.P.; Liu, K.Y.; Huang, X.J.; Sun, Y.Q. Co-Reactivation of Cytomegalovirus and Epstein-Barr Virus Was Associated With Poor Prognosis After Allogeneic Stem Cell Transplantation. Front. Immunol. 2020, 11, 620891. [CrossRef]

32. Lachance, P.; Chen, J.; Featherstone, R.; Sligl, W.I. Association Between Cytomegalovirus Reactivation and Clinical Outcomes in Immunocompetent Critically Ill Patients: A Systematic Review and Meta-Analysis. Open Forum Infect. Dis. 2017, 4, ofx029. [CrossRef]

33. Imlay, H.; Dasgupta, S.; Boeckh, M.; Stapleton, R.D.; Rubenfeld, G.D.; Chen, Y.; Limaye, A.P. Risk Factors for Cytomegalovirus Reactivation and Association With Outcomes in Critically Ill Adults With Sepsis: A Pooled Analysis of Prospective Studies. J. Infect. Dis. 2021, 223, 2108-2112. [CrossRef]

34. Docke, W.D.; Kiessling, C.; Worm, M.; Friedrich, M.; Pruss, A.; Weitz, M.; Prosch, S.; Kern, F.; Volk, H.D.; Sterry, W.; et al. Subclinical activation of latent cytomegalovirus (CMV) infection and anti-CMV immune response in patients with atopic dermatitis. Br. J. Dermatol. 2003, 148, 954-963. [CrossRef] 
35. Paolucci, S.; Cassaniti, I.; Novazzi, F.; Fiorina, L.; Piralla, A.; Comolli, G.; Bruno, R.; Maserati, R.; Gulminetti, R.; Novati, S.; et al. EBV DNA increase in COVID-19 patients with impaired lymphocyte subpopulation count. Int. J. Infect. Dis. 2021, 104, 315-319. [CrossRef] [PubMed]

36. Ota, Y.; Kaneko, Y.; Takeuchi, T. Association between mortality and cytomegalovirus reactivation during remission induction therapy in patients with rheumatic diseases. Clin. Exp. Rheumatol. 2020.

37. Lefranc, M.P. Nomenclature of the human T cell receptor genes. Curr. Protoc. Immunol. 2001, 40, A-1O. [CrossRef] [PubMed]

38. Willcox, C.R.; Davey, M.S.; Willcox, B.E. Development and Selection of the Human Vgamma9Vdelta2( $\left.{ }^{+}\right)$T-Cell Repertoire. Front. Immunol. 2018, 9, 1501. [CrossRef] [PubMed]

39. Papadopoulou, M.; Tieppo, P.; McGovern, N.; Gosselin, F.; Chan, J.K.Y.; Goetgeluk, G.; Dauby, N.; Cogan, A.; Donner, C.; Ginhoux, F.; et al. TCR Sequencing Reveals the Distinct Development of Fetal and Adult Human Vgamma9Vdelta2 T Cells. J. Immunol. 2019, 203, 1468-1479. [CrossRef]

40. Vermijlen, D.; Prinz, I. Ontogeny of Innate T Lymphocytes-Some Innate Lymphocytes are More Innate than Others. Front. Immunol. 2014, 5, 486. [CrossRef]

41. Deseke, M.; Prinz, I. Ligand recognition by the gammadelta TCR and discrimination between homeostasis and stress conditions. Cell Mol. Immunol. 2020, 17, 914-924. [CrossRef]

42. Daguzan, C.; Moulin, M.; Kulyk-Barbier, H.; Davrinche, C.; Peyrottes, S.; Champagne, E. Aminobisphosphonates Synergize with Human Cytomegalovirus To Activate the Antiviral Activity of Vgamma9Vdelta2 Cells. J. Immunol. 2016, 196, $2219-2229$. [CrossRef]

43. Jameson, J.M.; Cruz, J.; Costanzo, A.; Terajima, M.; Ennis, F.A. A role for the mevalonate pathway in the induction of subtype cross-reactive immunity to influenza A virus by human gammadelta T lymphocytes. Cell Immunol. 2010, 264, 71-77. [CrossRef]

44. Gruenbacher, G.; Nussbaumer, O.; Gander, H.; Steiner, B.; Leonhartsberger, N.; Thurnher, M. Stress-related and homeostatic cytokines regulate Vgamma9Vdelta2 T-cell surveillance of mevalonate metabolism. Oncoimmunology 2014, 3, e953410. [CrossRef] [PubMed]

45. Gruenbacher, G.; Thurnher, M. Mevalonate Metabolism in Immuno-Oncology. Front. Immunol. 2017, 8, 1714. [CrossRef]

46. Gober, H.J.; Kistowska, M.; Angman, L.; Jeno, P.; Mori, L.; De Libero, G. Human T cell receptor gammadelta cells recognize endogenous mevalonate metabolites in tumor cells. J. Exp. Med. 2003, 197, 163-168. [CrossRef] [PubMed]

47. Herrmann, T.; Fichtner, A.S.; Karunakaran, M.M. An Update on the Molecular Basis of Phosphoantigen Recognition by Vgamma9Vdelta2 T Cells. Cells 2020, 9, 1433. [CrossRef] [PubMed]

48. Rigau, M.; Ostrouska, S.; Fulford, T.S.; Johnson, D.N.; Woods, K.; Ruan, Z.; McWilliam, H.E.G.; Hudson, C.; Tutuka, C.; Wheatley, A.K.; et al. Butyrophilin 2A1 is essential for phosphoantigen reactivity by gammadelta T cells. Science 2020, 367, eaay5516. [CrossRef]

49. Karunakaran, M.M.; Willcox, C.R.; Salim, M.; Paletta, D.; Fichtner, A.S.; Noll, A.; Starick, L.; Nohren, A.; Begley, C.R.; Berwick, K.A.; et al. Butyrophilin-2A1 Directly Binds Germline-Encoded Regions of the Vgamma9Vdelta2 TCR and Is Essential for Phosphoantigen Sensing. Immunity 2020, 52, 487-498. [CrossRef]

50. Harly, C.; Guillaume, Y.; Nedellec, S.; Peigne, C.M.; Monkkonen, H.; Monkkonen, J.; Li, J.; Kuball, J.; Adams, E.J.; Netzer, S.; et al. Key implication of CD277/butyrophilin-3 (BTN3A) in cellular stress sensing by a major human gammadelta T-cell subset. Blood 2012, 120, 2269-2279. [CrossRef]

51. Sandstrom, A.; Peigne, C.M.; Leger, A.; Crooks, J.E.; Konczak, F.; Gesnel, M.C.; Breathnach, R.; Bonneville, M.; Scotet, E.; Adams, E.J. The Intracellular B30.2 Domain of Butyrophilin 3A1 Binds Phosphoantigens to Mediate Activation of Human Vgamma9Vdelta2 T Cells. Immunity 2014, 40, 490-500. [CrossRef]

52. Gu, S.; Borowska, M.T.; Boughter, C.T.; Adams, E.J. Butyrophilin3A proteins and Vgamma9Vdelta2 T cell activation. Semin. Cell Dev. Biol. 2018, 84, 65-74. [CrossRef]

53. Salim, M.; Knowles, T.J.; Baker, A.T.; Davey, M.S.; Jeeves, M.; Sridhar, P.; Wilkie, J.; Willcox, C.R.; Kadri, H.; Taher, T.E.; et al. BTN3A1 Discriminates gammadelta T Cell Phosphoantigens from Nonantigenic Small Molecules via a Conformational Sensor in Its B30.2 Domain. ACS Chem. Biol. 2017, 12, 2631-2643. [CrossRef] [PubMed]

54. Rhodes, D.A.; Chen, H.C.; Williamson, J.C.; Hill, A.; Yuan, J.; Smith, S.; Rhodes, H.; Trowsdale, J.; Lehner, P.J.; Herrmann, T.; et al. Regulation of Human gammadelta T Cells by BTN3A1 Protein Stability and ATP-Binding Cassette Transporters. Front. Immunol. 2018, 9, 662. [CrossRef] [PubMed]

55. Vantourout, P.; Laing, A.; Woodward, M.J.; Zlatareva, I.; Apolonia, L.; Jones, A.W.; Snijders, A.P.; Malim, M.H.; Hayday, A.C. Heteromeric interactions regulate butyrophilin (BTN) and BTN-like molecules governing gammadelta T cell biology. Proc. Natl. Acad. Sci. USA 2018, 115, 1039-1044. [CrossRef] [PubMed]

56. Jandke, A.; Melandri, D.; Monin, L.; Ushakov, D.S.; Laing, A.G.; Vantourout, P.; East, P.; Nitta, T.; Narita, T.; Takayanagi, H.; et al. Butyrophilin-like proteins display combinatorial diversity in selecting and maintaining signature intraepithelial gammadelta $\mathrm{T}$ cell compartments. Nat. Commun. 2020, 11, 3769. [CrossRef]

57. Melandri, D.; Zlatareva, I.; Chaleil, R.A.G.; Dart, R.J.; Chancellor, A.; Nussbaumer, O.; Polyakova, O.; Roberts, N.A.; Wesch, D.; Kabelitz, D.; et al. The gammadeltaTCR combines innate immunity with adaptive immunity by utilizing spatially distinct regions for agonist selection and antigen responsiveness. Nat. Immunol. 2018, 19, 1352-1365. [CrossRef] [PubMed] 
58. Ravens, S.; Schultze-Florey, C.; Raha, S.; Sandrock, I.; Drenker, M.; Oberdorfer, L.; Reinhardt, A.; Ravens, I.; Beck, M.; Geffers, R.; et al. Human gammadelta T cells are quickly reconstituted after stem-cell transplantation and show adaptive clonal expansion in response to viral infection. Nat. Immunol. 2017, 18, 393-401. [CrossRef]

59. Davey, M.S.; Willcox, C.R.; Baker, A.T.; Hunter, S.; Willcox, B.E. Recasting Human Vdelta1 Lymphocytes in an Adaptive Role. Trends Immunol. 2018, 39, 446-459. [CrossRef]

60. Kallemeijn, M.J.; Boots, A.M.H.; van der Klift, M.Y.; Brouwer, E.; Abdulahad, W.H.; Verhaar, J.A.N.; van Dongen, J.J.M.; Langerak, A.W. Ageing and latent CMV infection impact on maturation, differentiation and exhaustion profiles of T-cell receptor gammadelta T-cells. Sci. Rep. 2017, 7, 5509. [CrossRef]

61. Sant, S.; Jenkins, M.R.; Dash, P.; Watson, K.A.; Wang, Z.; Pizzolla, A.; Koutsakos, M.; Nguyen, T.H.; Lappas, M.; Crowe, J.; et al Human gammadelta T-cell receptor repertoire is shaped by influenza viruses, age and tissue compartmentalisation. Clin. Transl. Immunol. 2019, 8, e1079. [CrossRef]

62. Ryan, P.L.; Sumaria, N.; Holland, C.J.; Bradford, C.M.; Izotova, N.; Grandjean, C.L.; Jawad, A.S.; Bergmeier, L.A.; Pennington, D.J. Heterogeneous yet stable Vdelta2(+) T-cell profiles define distinct cytotoxic effector potentials in healthy human individuals. Proc. Natl. Acad. Sci. USA 2016, 113, 14378-14383. [CrossRef] [PubMed]

63. Xi, X.; Han, X.; Li, L.; Zhao, Z. gammadelta T cells response to Mycobacterium tuberculosis in pulmonary tuberculosis patients using preponderant complementary determinant region 3 sequence. Indian J. Med Res. 2011, 134, 356-361.

64. Ding, Y.; Ma, F.; Wang, Z.; Li, B. Characteristics of the Vdelta2 CDR3 Sequence of Peripheral gammadelta T Cells in Patients with Pulmonary Tuberculosis and Identification of a New Tuberculosis-Related Antigen Peptide. Clin. Vaccine Immunol. 2015, 22, 761-768. [CrossRef]

65. Uyemura, K.; Band, H.; Ohmen, J.; Brenner, M.B.; Rea, T.H.; Modlin, R.L. Gamma delta T cells in leprosy lesions. Curr. Top. Microbiol. Immunol. 1991, 173, 203-207. [PubMed]

66. Uyemura, K.; Deans, R.J.; Band, H.; Ohmen, J.; Panchamoorthy, G.; Morita, C.T.; Rea, T.H.; Modlin, R.L. Evidence for clonal selection of gamma/delta T cells in response to a human pathogen. J. Exp. Med. 1991, 174, 683-692. [CrossRef]

67. Huang, D.; Chen, C.Y.; Zhang, M.; Qiu, L.; Shen, Y.; Du, G.; Zhou, K.; Wang, R.; Chen, Z.W. Clonal immune responses of Mycobacterium-specific gammadelta T cells in tuberculous and non-tuberculous tissues during M. tuberculosis infection. PLoS ONE 2012, 7, e30631. [CrossRef]

68. Papadopoulou, M.; Dimova, T.; Shey, M.; Briel, L.; Veldtsman, H.; Khomba, N.; Africa, H.; Steyn, M.; Hanekom, W.A.; Scriba, T.J.; et al. Fetal public Vgamma9Vdelta2 T cells expand and gain potent cytotoxic functions early after birth. Proc. Natl. Acad. Sci. USA 2020, 117, 18638-18648. [CrossRef]

69. Ravens, S.; Fichtner, A.S.; Willers, M.; Torkornoo, D.; Pirr, S.; Schoning, J.; Deseke, M.; Sandrock, I.; Bubke, A.; Wilharm, A.; et al. Microbial exposure drives polyclonal expansion of innate gammadelta T cells immediately after birth. Proc. Natl. Acad. Sci. USA 2020, 117, 18649-18660. [CrossRef] [PubMed]

70. Davey, M.S.; Willcox, C.R.; Joyce, S.P.; Ladell, K.; Kasatskaya, S.A.; McLaren, J.E.; Hunter, S.; Salim, M.; Mohammed, F.; Price, D.A.; et al. Clonal selection in the human Vdelta1 $\mathrm{T}$ cell repertoire indicates gammadelta TCR-dependent adaptive immune surveillance. Nat. Commun. 2017, 8, 14760. [CrossRef]

71. Ribeiro, S.T.; Ribot, J.C.; Silva-Santos, B. Five Layers of Receptor Signaling in gammadelta T-Cell Differentiation and Activation. Front. Immunol. 2015, 6, 15. [CrossRef] [PubMed]

72. Silva-Santos, B.; Strid, J. Working in "NK Mode": Natural Killer Group 2 Member D and Natural Cytotoxicity Receptors in Stress-Surveillance by gammadelta T Cells. Front. Immunol. 2018, 9, 851. [CrossRef]

73. Silva-Santos, B.; Mensurado, S.; Coffelt, S.B. gammadelta T cells: Pleiotropic immune effectors with therapeutic potential in cancer. Nat. Rev. Cancer 2019, 392-404. [CrossRef] [PubMed]

74. Simoes, A.E.; Di Lorenzo, B.; Silva-Santos, B. Molecular Determinants of Target Cell Recognition by Human gammadelta T Cells. Front. Immunol. 2018, 9, 929. [CrossRef]

75. Nachmani, D.; Stern-Ginossar, N.; Sarid, R.; Mandelboim, O. Diverse herpesvirus microRNAs target the stress-induced immune ligand MICB to escape recognition by natural killer cells. Cell Host Microbe 2009, 5, 376-385. [CrossRef]

76. Tuengel, J.; Ranchal, S.; Maslova, A.; Aulakh, G.; Papadopoulou, M.; Drissler, S.; Cai, B.; Mohsenzadeh-Green, C.; Soudeyns, H.; Mostafavi, S.; et al. Characterization of Adaptive-like gammadelta T Cells in Ugandan Infants during Primary Cytomegalovirus Infection. Viruses 2021, 13, 1987. [CrossRef]

77. Voigt, S.; Schaffrath Rosario, A.; Mankertz, A. Cytomegalovirus Seroprevalence Among Children and Adolescents in Germany: Data From the German Health Interview and Examination Survey for Children and Adolescents (KiGGS), 2003-2006. Open Forum Infect. Dis. 2016, 3, ofv193. [CrossRef]

78. Cannon, M.J.; Schmid, D.S.; Hyde, T.B. Review of cytomegalovirus seroprevalence and demographic characteristics associated with infection. Rev. Med. Virol. 2010, 20, 202-213. [CrossRef]

79. Soderberg-Naucler, C.; Fish, K.N.; Nelson, J.A. Reactivation of latent human cytomegalovirus by allogeneic stimulation of blood cells from healthy donors. Cell 1997, 91, 119-126. [CrossRef]

80. Grinde, B. Herpesviruses: Latency and reactivation-Viral strategies and host response. J. Oral Microbiol. 2013, 5. [CrossRef]

81. Sinclair, J.; Sissons, P. Latency and reactivation of human cytomegalovirus. J. Gen. Virol. 2006, 87, 1763-1779. [CrossRef] [PubMed] 
82. Knight, A.; Madrigal, A.J.; Grace, S.; Sivakumaran, J.; Kottaridis, P.; Mackinnon, S.; Travers, P.J.; Lowdell, M.W. The role of Vdelta2-negative gammadelta $\mathrm{T}$ cells during cytomegalovirus reactivation in recipients of allogeneic stem cell transplantation. Blood 2010, 116, 2164-2172. [CrossRef]

83. Puig-Pey, I.; Bohne, F.; Benitez, C.; Lopez, M.; Martinez-Llordella, M.; Oppenheimer, F.; Lozano, J.J.; Gonzalez-Abraldes, J.; Tisone, G.; Rimola, A.; et al. Characterization of gammadelta T cell subsets in organ transplantation. Transpl. Int. 2010, 23, $1045-1055$. [CrossRef]

84. Kaminski, H.; Menard, C.; El Hayani, B.; Adjibabi, A.N.; Marseres, G.; Courant, M.; Zouine, A.; Pitard, V.; Garrigue, I.; Burrel, S.; et al. Characterization of a Unique gammadelta T-Cell Subset as a Specific Marker of Cytomegalovirus Infection Severity. J. Infect. Dis. 2021, 223, 655-666. [CrossRef] [PubMed]

85. Gaballa, A.; Alagrafi, F.; Uhlin, M.; Stikvoort, A. Revisiting the Role of gammadelta T Cells in Anti-CMV Immune Response after Transplantation. Viruses 2021, 13, 1031. [CrossRef]

86. Stankovic, S.; Davey, M.S.; Shaw, E.M.; von Borstel, A.; Cristiano, Y.; Levvey, B.J.; Rossjohn, J.; Westall, G.P.; Snell, G.I.; Brooks, A.G.; et al. Cytomegalovirus replication is associated with enrichment of distinct gammadelta T cell subsets following lung transplantation: A novel therapeutic approach? J. Heart Lung Transplant. 2020, 39, 1300-1312. [CrossRef] [PubMed]

87. Lee, S.; Affandi, J.S.; Irish, A.B.; Price, P. Cytomegalovirus infection alters phenotypes of different gammadelta T-cell subsets in renal transplant recipients with long-term stable graft function. J. Med. Virol. 2017, 89, 1442-1452. [CrossRef] [PubMed]

88. Dechanet, J.; Merville, P.; Lim, A.; Retiere, C.; Pitard, V.; Lafarge, X.; Michelson, S.; Meric, C.; Hallet, M.M.; Kourilsky, P.; et al. Implication of gammadelta T cells in the human immune response to cytomegalovirus. J. Clin. Investig. 1999, 103, 1437-1449. [CrossRef] [PubMed]

89. Lafarge, X.; Merville, P.; Cazin, M.C.; Berge, F.; Potaux, L.; Moreau, J.F.; Dechanet-Merville, J. Cytomegalovirus infection in transplant recipients resolves when circulating gammadelta $\mathrm{T}$ lymphocytes expand, suggesting a protective antiviral role. J. Infect. Dis. 2001, 184, 533-541. [CrossRef] [PubMed]

90. Kaminski, H.; Garrigue, I.; Couzi, L.; Taton, B.; Bachelet, T.; Moreau, J.F.; Dechanet-Merville, J.; Thiebaut, R.; Merville, P. Surveillance of gammadelta T Cells Predicts Cytomegalovirus Infection Resolution in Kidney Transplants. J. Am. Soc. Nephrol. 2016, 27, 637-645. [CrossRef] [PubMed]

91. Pitard, V.; Roumanes, D.; Lafarge, X.; Couzi, L.; Garrigue, I.; Lafon, M.E.; Merville, P.; Moreau, J.F.; Dechanet-Merville, J. Long-term expansion of effector/memory Vdelta2-gammadelta T cells is a specific blood signature of CMV infection. Blood 2008, 112, 1317-1324. [CrossRef] [PubMed]

92. Scheper, W.; van Dorp, S.; Kersting, S.; Pietersma, F.; Lindemans, C.; Hol, S.; Heijhuurs, S.; Sebestyen, Z.; Grunder, C.; Marcu-Malina, V.; et al. gammadeltaT cells elicited by CMV reactivation after allo-SCT cross-recognize CMV and leukemia. Leukemia 2013, 27, 1328-1338. [CrossRef] [PubMed]

93. Scheper, W.; Sebestyen, Z.; Kuball, J. Cancer Immunotherapy Using gammadeltaT Cells: Dealing with Diversity. Front. Immunol. 2014, 5, 601. [CrossRef]

94. Arruda, L.C.M.; Gaballa, A.; Uhlin, M. Graft gammadelta TCR Sequencing Identifies Public Clonotypes Associated with Hematopoietic Stem Cell Transplantation Efficacy in Acute Myeloid Leukemia Patients and Unravels Cytomegalovirus Impact on Repertoire Distribution. J. Immunol. 2019, 202, 1859-1870. [CrossRef]

95. Arruda, L.C.M.; Gaballa, A.; Uhlin, M. Impact of gammadelta T cells on clinical outcome of hematopoietic stem cell transplantation: Systematic review and meta-analysis. Blood Adv. 2019, 3, 3436-3448. [CrossRef] [PubMed]

96. Prinz, I.; Thamm, K.; Port, M.; Weissinger, E.M.; Stadler, M.; Gabaev, I.; Jacobs, R.; Ganser, A.; Koenecke, C. Donor Vdelta1+ gammadelta $\mathrm{T}$ cells expand after allogeneic hematopoietic stem cell transplantation and show reactivity against CMV-infected cells but not against progressing B-CLL. Exp. Hematol. Oncol. 2013, 2, 14. [CrossRef] [PubMed]

97. Roux, A.; Mourin, G.; Larsen, M.; Fastenackels, S.; Urrutia, A.; Gorochov, G.; Autran, B.; Donner, C.; Sidi, D.; Sibony-Prat, J.; et al. Differential impact of age and cytomegalovirus infection on the gammadelta T cell compartment. J. Immunol. 2013, 191, 1300-1306. [CrossRef] [PubMed]

98. Vermijlen, D.; Brouwer, M.; Donner, C.; Liesnard, C.; Tackoen, M.; Van Rysselberge, M.; Twite, N.; Goldman, M.; Marchant, A.; Willems, F. Human cytomegalovirus elicits fetal gammadelta T cell responses in utero. J. Exp. Med. 2010, 207, 807-821. [CrossRef] [PubMed]

99. Willcox, C.R.; Pitard, V.; Netzer, S.; Couzi, L.; Salim, M.; Silberzahn, T.; Moreau, J.F.; Hayday, A.C.; Willcox, B.E.; DechanetMerville, J. Cytomegalovirus and tumor stress surveillance by binding of a human gammadelta $\mathrm{T}$ cell antigen receptor to endothelial protein C receptor. Nat. Immunol. 2012, 13, 872-879. [CrossRef] [PubMed]

100. Willcox, C.R.; Vantourout, P.; Salim, M.; Zlatareva, I.; Melandri, D.; Zanardo, L.; George, R.; Kjaer, S.; Jeeves, M.; Mohammed, F.; et al. Butyrophilin-like 3 Directly Binds a Human Vgamma4 $\left({ }^{+}\right)$T Cell Receptor Using a Modality Distinct from Clonally-Restricted Antigen. Immunity 2019, 51, 813-825.e4. [CrossRef]

101. Jaganjac, M.; Matijevic, T.; Cindric, M.; Cipak, A.; Mrakovcic, L.; Gubisch, W.; Zarkovic, N. Induction of CMV-1 promoter by 4-hydroxy-2-nonenal in human embryonic kidney cells. Acta Biochim. Pol. 2010, 57, 179-183. [CrossRef]

102. Lee, Y.L.; Liu, C.E.; Cho, W.L.; Kuo, C.L.; Cheng, W.L.; Huang, C.S.; Liu, C.S. Presence of cytomegalovirus DNA in leucocytes is associated with increased oxidative stress and subclinical atherosclerosis in healthy adults. Biomarkers 2014, 19, 109-113. [CrossRef] 
103. Harly, C.; Joyce, S.P.; Domblides, C.; Bachelet, T.; Pitard, V.; Mannat, C.; Pappalardo, A.; Couzi, L.; Netzer, S.; Massara, L.; et al. Human gammadelta $\mathrm{T}$ cell sensing of AMPK-dependent metabolic tumor reprogramming through TCR recognition of EphA2. Sci. Immunol. 2021, 6, eaba9010. [CrossRef]

104. Marlin, R.; Pappalardo, A.; Kaminski, H.; Willcox, C.R.; Pitard, V.; Netzer, S.; Khairallah, C.; Lomenech, A.M.; Harly, C.; Bonneville, M.; et al. Sensing of cell stress by human gammadelta TCR-dependent recognition of annexin A2. Proc. Natl. Acad. Sci. USA 2017, 114, 3163-3168. [CrossRef] [PubMed]

105. Luzuriaga, K.; Sullivan, J.L. Infectious mononucleosis. N. Engl. J. Med. 2010, 362, 1993-2000. [CrossRef] [PubMed]

106. Cohen, J.I. Optimal treatment for chronic active Epstein-Barr virus disease. Pediatr. Transplant 2009, 13, 393-396. [CrossRef] [PubMed]

107. Davis, M.M.; Brodin, P. Rebooting Human Immunology. Annu. Rev. Immunol. 2018, 36, 843-864. [CrossRef]

108. Dominguez-Andres, J.; Netea, M.G. Impact of Historic Migrations and Evolutionary Processes on Human Immunity. Trends Immunol. 2019, 40, 1105-1119. [CrossRef]

109. Hislop, A.D.; Taylor, G.S.; Sauce, D.; Rickinson, A.B. Cellular responses to viral infection in humans: Lessons from Epstein-Barr virus. Annu. Rev. Immunol. 2007, 25, 587-617. [CrossRef]

110. Taylor, G.S.; Long, H.M.; Brooks, J.M.; Rickinson, A.B.; Hislop, A.D. The immunology of Epstein-Barr virus-induced disease. Annu. Rev. Immunol. 2015, 33, 787-821. [CrossRef]

111. Long, H.M.; Meckiff, B.J.; Taylor, G.S. The T-cell Response to Epstein-Barr Virus-New Tricks From an Old Dog. Front. Immunol. 2019, 10, 2193. [CrossRef]

112. Becnel, D.; Abdelghani, R.; Nanbo, A.; Avilala, J.; Kahn, J.; Li, L.; Lin, Z. Pathogenic Role of Epstein-Barr Virus in Lung Cancers. Viruses 2021, 13, 877. [CrossRef]

113. Montes-Mojarro, I.A.; Fend, F.; Quintanilla-Martinez, L. EBV and the Pathogenesis of NK/T Cell Lymphoma. Cancers 2021, 13, 1414. [CrossRef] [PubMed]

114. Munz, C. Cytotoxicity in Epstein Barr virus specific immune control. Curr. Opin. Virol. 2021, 46, 1-8. [CrossRef] [PubMed]

115. Babcock, G.J.; Decker, L.L.; Volk, M.; Thorley-Lawson, D.A. EBV persistence in memory B cells in vivo. Immunity 1998, 9, 395-404. [CrossRef]

116. Babcock, G.J.; Hochberg, D.; Thorley-Lawson, A.D. The expression pattern of Epstein-Barr virus latent genes in vivo is dependent upon the differentiation stage of the infected B cell. Immunity 2000, 13, 497-506. [CrossRef]

117. Hochberg, D.; Middeldorp, J.M.; Catalina, M.; Sullivan, J.L.; Luzuriaga, K.; Thorley-Lawson, D.A. Demonstration of the Burkitt's lymphoma Epstein-Barr virus phenotype in dividing latently infected memory cells in vivo. Proc. Natl. Acad. Sci. USA 2004, 101, 239-244. [CrossRef] [PubMed]

118. Thorley-Lawson, D.A. Epstein-Barr virus: Exploiting the immune system. Nat. Rev. Immunol. 2001, 1, 75-82. [CrossRef]

119. Djaoud, Z.; Guethlein, L.A.; Horowitz, A.; Azzi, T.; Nemat-Gorgani, N.; Olive, D.; Nadal, D.; Norman, P.J.; Munz, C.; Parham, P. Two alternate strategies for innate immunity to Epstein-Barr virus: One using NK cells and the other NK cells and gammadelta $\mathrm{T}$ cells. J. Exp. Med. 2017, 214, 1827-1841. [CrossRef] [PubMed]

120. Djaoud, Z.; Parham, P. Dimorphism in the TCRgamma-chain repertoire defines 2 types of human immunity to Epstein-Barr virus. Blood Adv. 2020, 4, 1198-1205. [CrossRef]

121. Bukowski, J.F.; Morita, C.T.; Brenner, M.B. Recognition and destruction of virus-infected cells by human gamma delta CTL. J. Immunol. 1994, 153, 5133-5140.

122. Azzi, T.; Lunemann, A.; Murer, A.; Ueda, S.; Beziat, V.; Malmberg, K.J.; Staubli, G.; Gysin, C.; Berger, C.; Munz, C.; et al. Role for early-differentiated natural killer cells in infectious mononucleosis. Blood 2014, 124, 2533-2543. [CrossRef]

123. Williams, H.; McAulay, K.; Macsween, K.F.; Gallacher, N.J.; Higgins, C.D.; Harrison, N.; Swerdlow, A.J.; Crawford, D.H. The immune response to primary EBV infection: A role for natural killer cells. Br. J. Haematol. 2005, 129, 266-274. [CrossRef] [PubMed]

124. Zhong, H.; Hu, X.; Janowski, A.B.; Storch, G.A.; Su, L.; Cao, L.; Yu, J.; Xu, J. Whole transcriptome profiling reveals major cell types in the cellular immune response against acute and chronic active Epstein-Barr virus infection. Sci. Rep. 2017, 7, 17775. [CrossRef] [PubMed]

125. De Paoli, P.; Gennari, D.; Martelli, P.; Cavarzerani, V.; Comoretto, R.; Santini, G. Gamma delta T cell receptor-bearing lymphocytes during Epstein-Barr virus infection. J. Infect. Dis. 1990, 161, 1013-1016. [CrossRef]

126. Bottino, C.; Tambussi, G.; Ferrini, S.; Ciccone, E.; Varese, P.; Mingari, M.C.; Moretta, L.; Moretta, A. Two subsets of human T lymphocytes expressing gamma/delta antigen receptor are identifiable by monoclonal antibodies directed to two distinct molecular forms of the receptor. J. Exp. Med. 1988, 168, 491-505. [CrossRef]

127. Liu, J.; Bian, Z.; Wang, X.; Xu, L.P.; Fu, Q.; Wang, C.; Chang, Y.J.; Wang, Y.; Zhang, X.H.; Jiang, Z.; et al. Inverse correlation of Vdelta2(+) T-cell recovery with EBV reactivation after haematopoietic stem cell transplantation. Br. J. Haematol. 2018, 180, 276-285. [CrossRef]

128. Fujishima, N.; Hirokawa, M.; Fujishima, M.; Yamashita, J.; Saitoh, H.; Ichikawa, Y.; Horiuchi, T.; Kawabata, Y.; Sawada, K.I. Skewed T cell receptor repertoire of Vdelta1 $\left(^{+}\right)$gammadelta T lymphocytes after human allogeneic haematopoietic stem cell transplantation and the potential role for Epstein-Barr virus-infected B cells in clonal restriction. Clin. Exp. Immunol. 2007, 149, 70-79. [CrossRef] 
129. Arai, Y.; Martin-Ruiz, C.M.; Takayama, M.; Abe, Y.; Takebayashi, T.; Koyasu, S.; Suematsu, M.; Hirose, N.; von Zglinicki, T. Inflammation, But Not Telomere Length, Predicts Successful Ageing at Extreme Old Age: A Longitudinal Study of Semisupercentenarians. EBioMedicine 2015, 2, 1549-1558. [CrossRef] [PubMed]

130. Hirai, Y.; Yamamoto, T.; Kimura, H.; Ito, Y.; Tsuji, K.; Miyake, T.; Morizane, S.; Suzuki, D.; Fujii, K.; Iwatsuki, K. Hydroa vacciniforme is associated with increased numbers of Epstein-Barr virus-infected gammadeltaT cells. J. Investig. Dermatol. 2012, 132, 1401-1408. [CrossRef] [PubMed]

131. Kimura, H.; Ito, Y.; Kawabe, S.; Gotoh, K.; Takahashi, Y.; Kojima, S.; Naoe, T.; Esaki, S.; Kikuta, A.; Sawada, A.; et al. EBVassociated T/NK-cell lymphoproliferative diseases in nonimmunocompromised hosts: Prospective analysis of 108 cases. Blood 2012, 119, 673-686. [CrossRef]

132. Wada, T.; Toga, A.; Sakakibara, Y.; Toma, T.; Hasegawa, M.; Takehara, K.; Shigemura, T.; Agematsu, K.; Yachie, A. Clonal expansion of Epstein-Barr virus (EBV)-infected gammadelta T cells in patients with chronic active EBV disease and hydroa vacciniforme-like eruptions. Int. J. Hematol. 2012, 96, 443-449. [CrossRef]

133. Iwatsuki, K.; Miyake, T.; Hirai, Y.; Yamamoto, T. Hydroa vacciniforme: A distinctive form of Epstein-Barr virus-associated T-cell lymphoproliferative disorders. Eur. J. Dermatol. 2019, 29, 21-28. [CrossRef] [PubMed]

134. Zumwalde, N.A.; Sharma, A.; Xu, X.; Ma, S.; Schneider, C.L.; Romero-Masters, J.C.; Hudson, A.W.; Gendron-Fitzpatrick, A.; Kenney, S.C.; Gumperz, J.E. Adoptively transferred Vgamma9Vdelta2 T cells show potent antitumor effects in a preclinical B cell lymphomagenesis model. JCI Insight 2017, 2, e9317. [CrossRef]

135. Al Hamed, R.; Bazarbachi, A.H.; Mohty, M. Epstein-Barr virus-related post-transplant lymphoproliferative disease (EBV-PTLD) in the setting of allogeneic stem cell transplantation: A comprehensive review from pathogenesis to forthcoming treatment modalities. Bone Marrow Transplant. 2020, 55, 25-39. [CrossRef] [PubMed]

136. Rothenberg, M.E.; Weber, W.E.; Longtine, J.A.; Hafler, D.A. Cytotoxic gamma delta I lymphocytes associated with an Epstein-Barr virus-induced posttransplantation lymphoproliferative disorder. Clin. Immunol. Immunopathol. 1996, 80, 266-272. [CrossRef] [PubMed]

137. Farnault, L.; Gertner-Dardenne, J.; Gondois-Rey, F.; Michel, G.; Chambost, H.; Hirsch, I.; Olive, D. Clinical evidence implicating gamma-delta T cells in EBV control following cord blood transplantation. Bone Marrow Transplant. 2013, 48, 1478-1479. [CrossRef] [PubMed]

138. Orsini, D.L.; Res, P.C.; Van Laar, J.M.; Muller, L.M.; Soprano, A.E.; Kooy, Y.M.; Tak, P.P.; Koning, F. A subset of V delta 1+ T cells proliferates in response to Epstein-Barr virus-transformed B cell lines in vitro. Scand. J. Immunol. 1993, 38, 335-340. [CrossRef] [PubMed]

139. Flament, C.; Benmerah, A.; Bonneville, M.; Triebel, F.; Mami-Chouaib, F. Human TCR-gamma/delta alloreactive response to HLA-DR molecules. Comparison with response of TCR-alpha/beta. J. Immunol. 1994, 153, 2890-2904. [PubMed]

140. Lam, V.; DeMars, R.; Chen, B.P.; Hank, J.A.; Kovats, S.; Fisch, P.; Sondel, P.M. Human T cell receptor-gamma delta-expressing T-cell lines recognize MHC-controlled elements on autologous EBV-LCL that are not HLA-A, -B, -C, -DR, -DQ, or -DP. J. Immunol. 1990, 145, 36-45.

141. Hacker, G.; Kromer, S.; Falk, M.; Heeg, K.; Wagner, H.; Pfeffer, K. V delta 1+ subset of human gamma delta T cells responds to ligands expressed by EBV-infected Burkitt lymphoma cells and transformed B lymphocytes. J. Immunol. 1992, 149, $3984-3989$.

142. Bartkowiak, J.; Kulczyck-Wojdala, D.; Blonski, J.Z.; Robak, T. Molecular diversity of gammadelta T cells in peripheral blood from patients with B-cell chronic lymphocytic leukaemia. Neoplasma 2002, 49, 86-90. [PubMed]

143. Almeida, A.R.; Correia, D.V.; Fernandes-Platzgummer, A.; da Silva, C.L.; da Silva, M.G.; Anjos, D.R.; Silva-Santos, B. Delta One T Cells for Immunotherapy of Chronic Lymphocytic Leukemia: Clinical-Grade Expansion/Differentiation and Preclinical Proof of Concept. Clin. Cancer Res. 2016, 22, 5795-5804. [CrossRef] [PubMed]

144. Siegers, G.M.; Dhamko, H.; Wang, X.H.; Mathieson, A.M.; Kosaka, Y.; Felizardo, T.C.; Medin, J.A.; Tohda, S.; Schueler, J.; Fisch, P.; et al. Human Vdelta1 gammadelta T cells expanded from peripheral blood exhibit specific cytotoxicity against B-cell chronic lymphocytic leukemia-derived cells. Cytotherapy 2011, 13, 753-764. [CrossRef] [PubMed]

145. Xiang, Z.; Liu, Y.; Zheng, J.; Liu, M.; Lv, A.; Gao, Y.; Hu, H.; Lam, K.T.; Chan, G.C.; Yang, Y.; et al. Targeted activation of human Vgamma9Vdelta2-T cells controls epstein-barr virus-induced B cell lymphoproliferative disease. Cancer Cell 2014, 26, 565-576. [CrossRef]

146. Looker, K.J.; Magaret, A.S.; Turner, K.M.; Vickerman, P.; Gottlieb, S.L.; Newman, L.M. Global estimates of prevalent and incident herpes simplex virus type 2 infections in 2012. PLoS ONE 2015, 10, e114989. [CrossRef]

147. Tognarelli, E.I.; Palomino, T.F.; Corrales, N.; Bueno, S.M.; Kalergis, A.M.; Gonzalez, P.A. Herpes Simplex Virus Evasion of Early Host Antiviral Responses. Front. Cell Infect. Microbiol 2019, 9, 127. [CrossRef]

148. Sciammas, R.; Bluestone, J.A. HSV-1 glycoprotein I-reactive TCR gamma delta cells directly recognize the peptide backbone in a conformationally dependent manner. J. Immunol. 1998, 161, 5187-5192.

149. Sciammas, R.; Bluestone, J.A. TCRgammadelta cells and viruses. Microbes Infect. 1999, 1, 203-212. [CrossRef]

150. Fitzpatrick, S.; Lausch, R.; Barrington, R.A. CCR6-Positive gammadelta T Cells Provide Protection Against Intracorneal HSV-1 Infection. Investig. Ophthalmol. Vis. Sci. 2019, 60, 3952-3962. [CrossRef]

151. Milligan, G.N.; Dudley-McClain, K.L.; Young, C.G.; Chu, C.F. T-cell-mediated mechanisms involved in resolution of genital herpes simplex virus type 2 (HSV-2) infection of mice. J. Reprod. Immunol. 2004, 61, 115-127. [CrossRef] 
152. Nishimura, H.; Yajima, T.; Kagimoto, Y.; Ohata, M.; Watase, T.; Kishihara, K.; Goshima, F.; Nishiyama, Y.; Yoshikai, Y. Intraepithelial gammadelta T cells may bridge a gap between innate immunity and acquired immunity to herpes simplex virus type 2 . $J$. Virol. 2004, 78, 4927-4930. [CrossRef] [PubMed]

153. Suryawanshi, A.; Veiga-Parga, T.; Rajasagi, N.K.; Reddy, P.B.; Sehrawat, S.; Sharma, S.; Rouse, B.T. Role of IL-17 and Th17 cells in herpes simplex virus-induced corneal immunopathology. J. Immunol. 2011, 187, 1919-1930. [CrossRef]

154. Kim, J.O.; Cha, H.R.; Kim, E.D.; Kweon, M.N. Pathological effect of IL-17A-producing TCRgammadelta $\left(^{+}\right)$T cells in mouse genital mucosa against HSV-2 infection. Immunol. Lett. 2012, 147, 34-40. [CrossRef]

155. Fernandez, M.A.; Yu, U.; Ferguson, A.L.; Wang, D.; Francis, E.; Roediger, B.; Weninger, W.; Cantrill, L.C.; Cunningham, A.L.; Alexander, S.I.; et al. Murine Skin-resident gammadeltaT Cells Impair the Immune Response to HSV in Skin. Infect. Disord. Drug Targets 2020, 20, 309-317. [CrossRef]

156. Maccario, R.; Revello, M.G.; Comoli, P.; Montagna, D.; Locatelli, F.; Gerna, G. HLA-unrestricted killing of HSV-1-infected mononuclear cells. Involvement of either gamma/delta+ or alpha/beta+ human cytotoxic T lymphocytes. J. Immunol. 1993, 150, 1437-1445. [PubMed]

157. Verjans, G.M.; Roest, R.W.; van der Kooi, A.; van Dijk, G.; van der Meijden, W.I.; Osterhaus, A. Isopentenyl pyrophosphatereactive Vgamma9Vdelta $2 \mathrm{~T}$ helper 1-like cells are the major gammadelta $\mathrm{T}$ cell subset recovered from lesions of patients with genital herpes. J. Infect. Dis. 2004, 190, 489-493. [CrossRef] [PubMed]

158. Di Luca, D.; Mirandola, P.; Ravaioli, T.; Dolcetti, R.; Frigatti, A.; Bovenzi, P.; Sighinolfi, L.; Monini, P.; Cassai, E. Human herpesviruses 6 and 7 in salivary glands and shedding in saliva of healthy and human immunodeficiency virus positive individuals. J. Med. Virol. 1995, 45, 462-468. [CrossRef]

159. Singh, N. Interactions between viruses in transplant recipients. Clin. Infect. Dis. 2005, 40, 430-436. [CrossRef] [PubMed]

160. Flamand, L.; Stefanescu, I.; Ablashi, D.V.; Menezes, J. Activation of the Epstein-Barr virus replicative cycle by human herpesvirus 6. J. Virol. 1993, 67, 6768-6777. [CrossRef] [PubMed]

161. Lusso, P. HHV-6 and the immune system: Mechanisms of immunomodulation and viral escape. J. Clin. Virol. 2006, 37 (Suppl. 1), S4-S10. [CrossRef]

162. Lusso, P.; Garzino-Demo, A.; Crowley, R.W.; Malnati, M.S. Infection of gamma/delta T lymphocytes by human herpesvirus 6 : Transcriptional induction of CD4 and susceptibility to HIV infection. J. Exp. Med. 1995, 181, 1303-1310. [CrossRef] [PubMed]

163. Lusso, P.; Malnati, M.; De Maria, A.; Balotta, C.; DeRocco, S.E.; Markham, P.D.; Gallo, R.C. Productive infection of CD4 ${ }^{+}$and $\mathrm{CD}^{+}$mature human $\mathrm{T}$ cell populations and clones by human herpesvirus 6. Transcriptional down-regulation of CD3. J. Immunol. 1991, 147, 685-691.

164. Imlach, S.; Leen, C.; Bell, J.E.; Simmonds, P. Phenotypic analysis of peripheral blood gammadelta T lymphocytes and their targeting by human immunodeficiency virus type 1 in vivo. Virology 2003, 305, 415-427. [CrossRef] [PubMed]

165. Mamimandjiami, A.I.; Mouinga-Ondeme, A.; Ramassamy, J.L.; Djuicy, D.D.; Afonso, P.V.; Mahe, A.; Lekana-Douki, J.B.; Cassar, O.; Gessain, A. Epidemiology and Genetic Variability of HHV-8/KSHV among Rural Populations and Kaposi's Sarcoma Patients in Gabon, Central Africa. Review of the Geographical Distribution of HHV-8 K1 Genotypes in Africa. Viruses 2021, $13,175$. [CrossRef] [PubMed]

166. Rohner, E.; Wyss, N.; Trelle, S.; Mbulaiteye, S.M.; Egger, M.; Novak, U.; Zwahlen, M.; Bohlius, J. HHV-8 seroprevalence: A global view. Syst. Rev. 2014, 3, 11. [CrossRef]

167. Munz, C. Natural Killer Cell Responses during Human gamma-Herpesvirus Infections. Vaccines 2021, 9, 655. [CrossRef] [PubMed]

168. Barcy, S.; De Rosa, S.C.; Vieira, J.; Diem, K.; Ikoma, M.; Casper, C.; Corey, L. Gamma delta+ T cells involvement in viral immune control of chronic human herpesvirus 8 infection. J. Immunol. 2008, 180, 3417-3425. [CrossRef]

169. Heininger, U.; Seward, J.F. Varicella. Lancet 2006, 368, 1365-1376. [CrossRef]

170. Gerada, C.; Campbell, T.M.; Kennedy, J.J.; McSharry, B.P.; Steain, M.; Slobedman, B.; Abendroth, A. Manipulation of the Innate Immune Response by Varicella Zoster Virus. Front. Immunol. 2020, 11, 1. [CrossRef]

171. Pedersen, A.; Hornsleth, A. Recurrent aphthous ulceration: A possible clinical manifestation of reactivation of varicella zoster or cytomegalovirus infection. J. Oral Pathol. Med. 1993, 22, 64-68. [CrossRef]

172. Pedersen, A.; Madsen, H.O.; Vestergaard, B.F.; Ryder, L.P. Varicella-zoster virus DNA in recurrent aphthous ulcers. Scand. J. Dent. Res. 1993, 101, 311-313. [CrossRef]

173. Natah, S.S.; Hayrinen-Immonen, R.; Hietanen, J.; Patinen, P.; Malmstrom, M.; Savilahti, E.; Konttinen, Y.T. Increased density of lymphocytes bearing gamma/delta T-cell receptors in recurrent aphthous ulceration (RAU). Int. J. Oral Maxillofac. Surg. 2000, 29, 375-380. [CrossRef]

174. Mendez, J.C.; Dockrell, D.H.; Espy, M.J.; Smith, T.F.; Wilson, J.A.; Harmsen, W.S.; Ilstrup, D.; Paya, C.V. Human beta-herpesvirus interactions in solid organ transplant recipients. J. Infect. Dis. 2001, 183, 179-184. [CrossRef] [PubMed]

175. Dockrell, D.H.; Prada, J.; Jones, M.F.; Patel, R.; Badley, A.D.; Harmsen, W.S.; Ilstrup, D.M.; Wiesner, R.H.; Krom, R.A.; Smith, T.F.; et al. Seroconversion to human herpesvirus 6 following liver transplantation is a marker of cytomegalovirus disease. J. Infect. Dis. 1997, 176, 1135-1140. [CrossRef]

176. Crocchiolo, R.; Giordano, L.; Rimondo, A.; Bologna, M.; Sarina, B.; Morabito, L.; Bramanti, S.; Castagna, L.; Mineri, R. Human Herpesvirus 6 replication predicts Cytomegalovirus reactivation after allogeneic stem cell transplantation from haploidentical donor. J. Clin. Virol. 2016, 84, 24-26. [CrossRef] [PubMed] 
177. DesJardin, J.A.; Gibbons, L.; Cho, E.; Supran, S.E.; Falagas, M.E.; Werner, B.G.; Snydman, D.R. Human herpesvirus 6 reactivation is associated with cytomegalovirus infection and syndromes in kidney transplant recipients at risk for primary cytomegalovirus infection. J. Infect. Dis. 1998, 178, 1783-1786. [CrossRef]

178. Ratnamohan, V.M.; Chapman, J.; Howse, H.; Bovington, K.; Robertson, P.; Byth, K.; Allen, R.; Cunningham, A.L. Cytomegalovirus and human herpesvirus 6 both cause viral disease after renal transplantation. Transplantation 1998, 66, 877-882. [CrossRef] [PubMed]

179. Sia, I.G.; Patel, R. New strategies for prevention and therapy of cytomegalovirus infection and disease in solid-organ transplant recipients. Clin. Microbiol. Rev. 2000, 13, 83-121. [CrossRef]

180. Katagiri, S.; Akahane, D.; Inukai, T.; Otsuki, S.; Yamada, A.; Moriyama, M.; Yamada, A.; Asano, M.; Yoshizawa, S.; Tanaka, Y.; et al. Elevation of HHV-6 viral load mimicking HHV-6 reactivation after second umbilical cord blood transplantation in chromosomally integrated human herpesvirus-6. J. Infect. Chemother. 2021, 1517-1519. [CrossRef]

181. Anderson-Smits, C.; Baker, E.R.; Hirji, I. Coinfection rates and clinical outcome data for cytomegalovirus and Epstein-Barr virus in post-transplant patients: A systematic review of the literature. Transpl Infect. Dis. 2020, 22, e13396. [CrossRef]

182. Aalto, S.M.; Linnavuori, K.; Peltola, H.; Vuori, E.; Weissbrich, B.; Schubert, J.; Hedman, L.; Hedman, K. Immunoreactivation of Epstein-Barr virus due to cytomegalovirus primary infection. J. Med. Virol. 1998, 56, 186-191. [CrossRef]

183. Armstrong, J.A.; Evans, A.S.; Rao, N.; Ho, M. Viral infections in renal transplant recipients. Infect. Immun. 1976, 14, 970-975. [CrossRef] [PubMed]

184. Hornef, M.W.; Bein, G.; Fricke, L.; Steinhoff, J.; Wagner, H.J.; Hinderer, W.; Sonneborn, H.H.; Kirchner, H. Coincidence of Epstein-Barr virus reactivation, cytomegalovirus infection, and rejection episodes in renal transplant recipients. Transplantation 1995, 60, 474-480. [CrossRef] [PubMed]

185. Anderson, R.A.; Liu, D.X.; Gompels, U.A. Definition of a human herpesvirus-6 betaherpesvirus-specific domain in glycoprotein $\mathrm{gH}$ that governs interaction with glycoprotein gL: Substitution of human cytomegalovirus glycoproteins permits group-specific complex formation. Virology 1996, 217, 517-526. [CrossRef]

186. Humar, A.; Michaels, M.; Monitoring, A.I.W.G.o.I.D. American Society of Transplantation recommendations for screening, monitoring and reporting of infectious complications in immunosuppression trials in recipients of organ transplantation. Am. J. Transplant. 2006, 6, 262-274. [CrossRef]

187. Arcenas, R.; Widen, R.H. Epstein-Barr virus reactivation after superinfection of the BJAB-B1 and P3HR-1 cell lines with cytomegalovirus. BMC Microbiol. 2002, 2, 20. [CrossRef]

188. Dechanet, J.; Merville, P.; Berge, F.; Bone-Mane, G.; Taupin, J.L.; Michel, P.; Joly, P.; Bonneville, M.; Potaux, L.; Moreau, J.F. Major expansion of gammadelta T lymphocytes following cytomegalovirus infection in kidney allograft recipients. J. Infect. Dis. 1999, 179, 1-8. [CrossRef]

189. Hayday, A.C.; Vantourout, P. The Innate Biologies of Adaptive Antigen Receptors. Annu. Rev. Immunol. 2020, 38, 487-510. [CrossRef] [PubMed]

190. Biradar, S.; Lotze, M.T.; Mailliard, R.B. The Unknown Unknowns: Recovering Gamma-Delta T Cells for Control of Human Immunodeficiency Virus (HIV). Viruses 2020, 12, 1455. [CrossRef]

191. Juno, J.A.; Kent, S.J. What Can Gamma Delta T Cells Contribute to an HIV Cure? Front. Cell Infect. Microbiol. 2020, 10, 233. [CrossRef]

192. Pauza, C.D.; Poonia, B.; Li, H.; Cairo, C.; Chaudhry, S. gammadelta T Cells in HIV Disease: Past, Present, and Future. Front. Immunol. 2014, 5, 687. [CrossRef]

193. Li, H.; Peng, H.; Ma, P.; Ruan, Y.; Su, B.; Ding, X.; Xu, C.; Pauza, C.D.; Shao, Y. Association between Vgamma2Vdelta2 T cells and disease progression after infection with closely related strains of HIV in China. Clin. Infect. Dis. 2008, 46, 1466-1472. [CrossRef] [PubMed]

194. Poles, M.A.; Barsoum, S.; Yu, W.; Yu, J.; Sun, P.; Daly, J.; He, T.; Mehandru, S.; Talal, A.; Markowitz, M.; et al. Human immunodeficiency virus type 1 induces persistent changes in mucosal and blood gammadelta $\mathrm{T}$ cells despite suppressive therapy. J. Virol. 2003, 77, 10456-10467. [CrossRef] [PubMed]

195. Chaudhry, S.; Cairo, C.; Venturi, V.; Pauza, C.D. The gammadelta T-cell receptor repertoire is reconstituted in HIV patients after prolonged antiretroviral therapy. AIDS 2013, 27, 1557-1562. [CrossRef] [PubMed]

196. Poccia, F.; Boullier, S.; Lecoeur, H.; Cochet, M.; Poquet, Y.; Colizzi, V.; Fournie, J.J.; Gougeon, M.L. Peripheral V gamma $9 /$ V delta $2 \mathrm{~T}$ cell deletion and anergy to nonpeptidic mycobacterial antigens in asymptomatic HIV-1-infected persons. J. Immunol. 1996, 157, 449-461. [PubMed]

197. Chevalier, M.F.; Bhatnagar, N.; Didier, C.; Lopez-Gonzalez, M.; Pavie, J.; Bollens, D.; Duvivier, C.; Collias, L.; Jung, C.; Scott-Algara, D.; et al. gammadelta T-cell subsets in HIV controllers: Potential role of Tgammadelta17 cells in the regulation of chronic immune activation. AIDS 2019, 33, 1283-1292. [CrossRef]

198. Riedel, D.J.; Sajadi, M.M.; Armstrong, C.L.; Cummings, J.S.; Cairo, C.; Redfield, R.R.; Pauza, C.D. Natural viral suppressors of HIV-1 have a unique capacity to maintain gammadelta T cells. AIDS 2009, 23, 1955-1964. [CrossRef]

199. De Paoli, P.; Gennari, D.; Martelli, P.; Basaglia, G.; Crovatto, M.; Battistin, S.; Santini, G. A subset of gamma delta lymphocytes is increased during HIV-1 infection. Clin. Exp. Immunol. 1991, 83, 187-191. [CrossRef] [PubMed]

200. Li, Z.; Li, W.; Li, N.; Jiao, Y.; Chen, D.; Cui, L.; Hu, Y.; Wu, H.; He, W. gammadelta T cells are involved in acute HIV infection and associated with AIDS progression. PLoS ONE 2014, 9, e106064. [CrossRef] 
201. Harris, L.D.; Klatt, N.R.; Vinton, C.; Briant, J.A.; Tabb, B.; Ladell, K.; Lifson, J.; Estes, J.D.; Price, D.A.; Hirsch, V.M.; et al. Mechanisms underlying gammadelta T-cell subset perturbations in SIV-infected Asian rhesus macaques. Blood 2010, 116, 4148-4157. [CrossRef]

202. Boullier, S.; Cochet, M.; Poccia, F.; Gougeon, M.L. CDR3-independent gamma delta V delta 1+ T cell expansion in the peripheral blood of HIV-infected persons. J. Immunol. 1995, 154, 1418-1431.

203. Hinz, T.; Wesch, D.; Friese, K.; Reckziegel, A.; Arden, B.; Kabelitz, D. T cell receptor gamma delta repertoire in HIV-1-infected individuals. Eur. J. Immunol. 1994, 24, 3044-3049. [CrossRef] [PubMed]

204. Olson, G.S.; Moore, S.W.; Richter, J.M.; Garber, J.J.; Bowman, B.A.; Rawlings, C.A.; Flagg, M.; Corleis, B.; Kwon, D.S. Increased frequency of systemic pro-inflammatory Vdelta $1\left(^{+}\right)$gammadelta T cells in HIV elite controllers correlates with gut viral load. Sci. Rep. 2018, 8, 16471. [CrossRef]

205. Dunne, P.J.; Maher, C.O.; Freeley, M.; Dunne, K.; Petrasca, A.; Orikiiriza, J.; Dunne, M.R.; Reidy, D.; O’Dea, S.; Loy, A.; et al. CD3epsilon Expression Defines Functionally Distinct Subsets of Vdelta1 T Cells in Patients With Human Immunodeficiency Virus Infection. Front. Immunol. 2018, 9, 940. [CrossRef]

206. Fenoglio, D.; Poggi, A.; Catellani, S.; Battaglia, F.; Ferrera, A.; Setti, M.; Murdaca, G.; Zocchi, M.R. Vdelta1 T lymphocytes producing IFN-gamma and IL-17 are expanded in HIV-1-infected patients and respond to Candida albicans. Blood 2009, 113, 6611-6618. [CrossRef] [PubMed]

207. Pellegrin, J.L.; Taupin, J.L.; Dupon, M.; Ragnaud, J.M.; Maugein, J.; Bonneville, M.; Moreau, J.F. Gammadelta T cells increase with Mycobacterium avium complex infection but not with tuberculosis in AIDS patients. Int. Immunol. 1999, 11, 1475-1478. [CrossRef]

208. Cimini, E.; Agrati, C.; D’Offizi, G.; Vlassi, C.; Casetti, R.; Sacchi, A.; Lionetti, R.; Bordoni, V.; Tumino, N.; Scognamiglio, P.; et al. Primary and Chronic HIV Infection Differently Modulates Mucosal Vdelta1 and Vdelta2 T-Cells Differentiation Profile and Effector Functions. PLoS ONE 2015, 10, e0129771. [CrossRef]

209. Strbo, N.; Alcaide, M.L.; Romero, L.; Bolivar, H.; Jones, D.; Podack, E.R.; Fischl, M.A. Loss of Intra-Epithelial Endocervical Gamma Delta (GD) 1 T Cells in HIV-Infected Women. Am. J. Reprod. Immunol. 2016, 75, 134-145. [CrossRef]

210. Klatt, N.R.; Funderburg, N.T.; Brenchley, J.M. Microbial translocation, immune activation, and HIV disease. Trends Microbiol. 2013, 21, 6-13. [CrossRef] [PubMed]

211. Poggi, A.; Carosio, R.; Fenoglio, D.; Brenci, S.; Murdaca, G.; Setti, M.; Indiveri, F.; Scabini, S.; Ferrero, E.; Zocchi, M.R. Migration of V delta 1 and V delta $2 \mathrm{~T}$ cells in response to CXCR3 and CXCR4 ligands in healthy donors and HIV-1-infected patients: Competition by HIV-1 Tat. Blood 2004, 103, 2205-2213. [CrossRef]

212. Morris, S.R.; Zhao, M.; Smith, D.M.; Vargas, M.V.; Little, S.J.; Gianella, S. Longitudinal Viral Dynamics in Semen During Early HIV Infection. Clin. Infect. Dis. 2017, 64, 428-434. [CrossRef]

213. Gianella, S.; Redd, A.D.; Grabowski, M.K.; Tobian, A.A.; Serwadda, D.; Newell, K.; Patel, E.U.; Kalibbala, S.; Ssebbowa, P.; Gray, R.H.; et al. Vaginal Cytomegalovirus Shedding Before and After Initiation of Antiretroviral Therapy in Rakai, Uganda. J. Infect. Dis. 2015, 212, 899-903. [CrossRef] [PubMed]

214. Waters, S.; Brook, E.; Lee, S.; Estiasari, R.; Ariyanto, I.; Price, P. HIV patients, healthy aging and transplant recipients can reveal the hidden footprints of CMV. Clin. Immunol. 2018, 187, 107-112. [CrossRef] [PubMed]

215. Looker, K.J.; Elmes, J.A.R.; Gottlieb, S.L.; Schiffer, J.T.; Vickerman, P.; Turner, K.M.E.; Boily, M.C. Effect of HSV-2 infection on subsequent HIV acquisition: An updated systematic review and meta-analysis. Lancet Infect. Dis. 2017, 17, 1303-1316. [CrossRef]

216. Barnabas, R.V.; Wasserheit, J.N.; Huang, Y.; Janes, H.; Morrow, R.; Fuchs, J.; Mark, K.E.; Casapia, M.; Mehrotra, D.V.; Buchbinder, S.P.; et al. Impact of herpes simplex virus type 2 on HIV-1 acquisition and progression in an HIV vaccine trial (the Step study). J. Acquir Immune Defic. Syndr. 2011, 57, 238-244. [CrossRef]

217. Freeman, E.E.; Weiss, H.A.; Glynn, J.R.; Cross, P.L.; Whitworth, J.A.; Hayes, R.J. Herpes simplex virus 2 infection increases HIV acquisition in men and women: Systematic review and meta-analysis of longitudinal studies. AIDS 2006, 20, 73-83. [CrossRef]

218. Brunetta, E.; Fogli, M.; Varchetta, S.; Bozzo, L.; Hudspeth, K.L.; Marcenaro, E.; Moretta, A.; Mavilio, D. Chronic HIV-1 viremia reverses NKG2A/NKG2C ratio on natural killer cells in patients with human cytomegalovirus co-infection. AIDS 2010, 24, 27-34. [CrossRef]

219. Della Chiesa, M.; Muccio, L.; Moretta, A. CMV induces rapid NK cell maturation in HSCT recipients. Immunol. Lett. 2013, 155, 11-13. [CrossRef] [PubMed]

220. Monsivais-Urenda, A.; Noyola-Cherpitel, D.; Hernandez-Salinas, A.; Garcia-Sepulveda, C.; Romo, N.; Baranda, L.; Lopez-Botet, M.; Gonzalez-Amaro, R. Influence of human cytomegalovirus infection on the NK cell receptor repertoire in children. Eur. J. Immunol. 2010, 40, 1418-1427. [CrossRef]

221. Mela, C.M.; Burton, C.T.; Imami, N.; Nelson, M.; Steel, A.; Gazzard, B.G.; Gotch, F.M.; Goodier, M.R. Switch from inhibitory to activating NKG2 receptor expression in HIV-1 infection: Lack of reversion with highly active antiretroviral therapy. AIDS 2005, 19, 1761-1769. [CrossRef]

222. Foley, B.; Cooley, S.; Verneris, M.R.; Pitt, M.; Curtsinger, J.; Luo, X.; Lopez-Verges, S.; Lanier, L.L.; Weisdorf, D.; Miller, J.S. Cytomegalovirus reactivation after allogeneic transplantation promotes a lasting increase in educated NKG2C+ natural killer cells with potent function. Blood 2012, 119, 2665-2674. [CrossRef]

223. Peppa, D.; Pedroza-Pacheco, I.; Pellegrino, P.; Williams, I.; Maini, M.K.; Borrow, P. Adaptive Reconfiguration of Natural Killer Cells in HIV-1 Infection. Front. Immunol. 2018, 9, 474. [CrossRef] [PubMed] 
224. Guma, M.; Cabrera, C.; Erkizia, I.; Bofill, M.; Clotet, B.; Ruiz, L.; Lopez-Botet, M. Human cytomegalovirus infection is associated with increased proportions of NK cells that express the CD94/NKG2C receptor in aviremic HIV-1-positive patients. J. Infect. Dis. 2006, 194, 38-41. [CrossRef]

225. Bjorkstrom, N.K.; Svensson, A.; Malmberg, K.J.; Eriksson, K.; Ljunggren, H.G. Characterization of natural killer cell phenotype and function during recurrent human HSV-2 infection. PLoS ONE 2011, 6, e27664. [CrossRef] [PubMed]

226. Hendricks, D.W.; Balfour, H.H., Jr.; Dunmire, S.K.; Schmeling, D.O.; Hogquist, K.A.; Lanier, L.L. Cutting edge: NKG2C(hi)CD57+ NK cells respond specifically to acute infection with cytomegalovirus and not Epstein-Barr virus. J. Immunol. 2014, 192, 4492-4496. [CrossRef] [PubMed]

227. Angelini, D.F.; Zambello, R.; Galandrini, R.; Diamantini, A.; Placido, R.; Micucci, F.; Poccia, F.; Semenzato, G.; Borsellino, G.; Santoni, A.; et al. NKG2A inhibits NKG2C effector functions of gammadelta T cells: Implications in health and disease. J. Leukoc Biol. 2011, 89, 75-84. [CrossRef] [PubMed]

228. Fausther-Bovendo, H.; Wauquier, N.; Cherfils-Vicini, J.; Cremer, I.; Debre, P.; Vieillard, V. NKG2C is a major triggering receptor involved in the V[delta]1 T cell-mediated cytotoxicity against HIV-infected CD4 T cells. AIDS 2008, 22, 217-226. [CrossRef]

229. Couzi, L.; Pitard, V.; Netzer, S.; Garrigue, I.; Lafon, M.E.; Moreau, J.F.; Taupin, J.L.; Merville, P.; Dechanet-Merville, J. Common features of gammadelta T cells and $\mathrm{CD} 8\left(^{+}\right)$alphabeta T cells responding to human cytomegalovirus infection in kidney transplant recipients. J. Infect. Dis. 2009, 200, 1415-1424. [CrossRef]

230. Barrett, L.; Stapleton, S.N.; Fudge, N.J.; Grant, M.D. Immune resilience in HIV-infected individuals seronegative for cytomegalovirus. AIDS 2014, 28, 2045-2049. [CrossRef] [PubMed]

231. Gianella, S.; Anderson, C.M.; Var, S.R.; Oliveira, M.F.; Lada, S.M.; Vargas, M.V.; Massanella, M.; Little, S.J.; Richman, D.D.; Strain, M.C.; et al. Replication of Human Herpesviruses Is Associated with Higher HIV DNA Levels during Antiretroviral Therapy Started at Early Phases of HIV Infection. J. Virol. 2016, 90, 3944-3952. [CrossRef]

232. Ariyanto, I.A.; Lee, S.; Estiasari, R.; Edmands, J.; Bela, B.; Soebandrio, A.; Price, P. Understanding the effects of CMV on gammadelta T-cell populations in HIV patients starting antiretroviral therapy. Clin. Immunol. 2021, 226, 108696. [CrossRef] [PubMed]

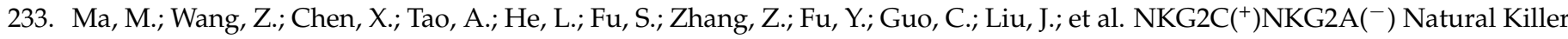
Cells are Associated with a Lower Viral Set Point and may Predict Disease Progression in Individuals with Primary HIV Infection. Front. Immunol. 2017, 8, 1176. [CrossRef] [PubMed]

234. Gondois-Rey, F.; Cheret, A.; Granjeaud, S.; Mallet, F.; Bidaut, G.; Lecuroux, C.; Ploquin, M.; Muller-Trutwin, M.; Rouzioux, C.; Avettand-Fenoel, V.; et al. NKG2C $\left(^{+}\right)$memory-like NK cells contribute to the control of HIV viremia during primary infection: Optiprim-ANRS 147. Clin. Transl. Immunol. 2017, 6, e150. [CrossRef]

235. Norris, S.; Doherty, D.G.; Collins, C.; McEntee, G.; Traynor, O.; Hegarty, J.E.; O'Farrelly, C. Natural T cells in the human liver: Cytotoxic lymphocytes with dual $\mathrm{T}$ cell and natural killer cell phenotype and function are phenotypically heterogenous and include Valpha24-JalphaQ and gammadelta T cell receptor bearing cells. Hum. Immunol. 1999, 60, 20-31. [CrossRef]

236. Kenna, T.; Golden-Mason, L.; Norris, S.; Hegarty, J.E.; O’Farrelly, C.; Doherty, D.G. Distinct subpopulations of gamma delta T cells are present in normal and tumor-bearing human liver. Clin. Immunol. 2004, 113, 56-63. [CrossRef]

237. Hunter, S.; Willcox, C.R.; Davey, M.S.; Kasatskaya, S.A.; Jeffery, H.C.; Chudakov, D.M.; Oo, Y.H.; Willcox, B.E. Human liver infiltrating gammadelta T cells are composed of clonally expanded circulating and tissue-resident populations. J. Hepatol. 2018, 69, 654-665. [CrossRef]

238. Seto, W.K.; Lo, Y.R.; Pawlotsky, J.M.; Yuen, M.F. Chronic hepatitis B virus infection. Lancet 2018, 392, 2313-2324. [CrossRef]

239. Spearman, C.W.; Dusheiko, G.M.; Hellard, M.; Sonderup, M. Hepatitis C. Lancet 2019, 394, 1451-1466. [CrossRef]

240. Martinez-Llordella, M.; Puig-Pey, I.; Orlando, G.; Ramoni, M.; Tisone, G.; Rimola, A.; Lerut, J.; Latinne, D.; Margarit, C.; Bilbao, I.; et al. Multiparameter immune profiling of operational tolerance in liver transplantation. Am. J. Transplant. 2007, 7, 309-319. [CrossRef] [PubMed]

241. Koshiba, T.; Li, Y.; Takemura, M.; Wu, Y.; Sakaguchi, S.; Minato, N.; Wood, K.J.; Haga, H.; Ueda, M.; Uemoto, S. Clinical, immunological, and pathological aspects of operational tolerance after pediatric living-donor liver transplantation. Transpl. Immunol. 2007, 17, 94-97. [CrossRef]

242. Kanayama, K.; Morise, K.; Nagura, H. Immunohistochemical study of T cell receptor gamma delta cells in chronic liver disease. Am. J. Gastroenterol. 1992, 87, 1018-1022.

243. Agrati, C.; D’Offizi, G.; Gougeon, M.L.; Malkovsky, M.; Sacchi, A.; Casetti, R.; Bordoni, V.; Cimini, E.; Martini, F. Innate gamma/delta T-cells during HIV infection: Terra relatively Incognita in novel vaccination strategies? AIDS Rev. 2011, 13, 3-12.

244. Agrati, C.; D'Offizi, G.; Narciso, P.; Abrignani, S.; Ippolito, G.; Colizzi, V.; Poccia, F. Vdelta1 T lymphocytes expressing a Th1 phenotype are the major gammadelta T cell subset infiltrating the liver of HCV-infected persons. Mol. Med. 2001, 7, 11-19. [CrossRef] [PubMed]

245. Ravens, S.; Hengst, J.; Schlapphoff, V.; Deterding, K.; Dhingra, A.; Schultze-Florey, C.; Koenecke, C.; Cornberg, M.; Wedemeyer, H.; Prinz, I. Human gammadelta T Cell Receptor Repertoires in Peripheral Blood Remain Stable Despite Clearance of Persistent Hepatitis C Virus Infection by Direct-Acting Antiviral Drug Therapy. Front Immunol. 2018, 9, 510. [CrossRef]

246. Par, G.; Rukavina, D.; Podack, E.R.; Horanyi, M.; Szekeres-Bartho, J.; Hegedus, G.; Paal, M.; Szereday, L.; Mozsik, G.; Par, A. Decrease in CD3-negative-CD8dim $\left(^{+}\right)$and Vdelta2/Vgamma9 $\mathrm{TcR}+$ peripheral blood lymphocyte counts, low perforin expression 
and the impairment of natural killer cell activity is associated with chronic hepatitis C virus infection. J. Hepatol. 2002, 37, 514-522. [CrossRef]

247. Ghosh, A.; Mondal, R.K.; Romani, S.; Bagchi, S.; Cairo, C.; Pauza, C.D.; Kottilil, S.; Poonia, B. Persistent gamma delta T-cell dysfunction in chronic HCV infection despite direct-acting antiviral therapy induced cure. J. Viral. Hepat. 2019, 26, 1105-1116. [CrossRef] [PubMed]

248. Conroy, M.J.; Mac Nicholas, R.; Taylor, M.; O’Dea, S.; Mulcahy, F.; Norris, S.; Doherty, D.G. Increased Frequencies of Circulating IFN-gamma-Producing Vdelta1 $\left(^{+}\right)$and Vdelta2 $\left({ }^{+}\right)$gammadelta T Cells in Patients with Asymptomatic Persistent Hepatitis B Virus Infection. Viral. Immunol. 2015, 28, 201-208. [CrossRef]

249. Chang, K.M.; Traum, D.; Park, J.J.; Ho, S.; Ojiro, K.; Wong, D.K.; Wahed, A.S.; Terrault, N.A.; Khalili, M.; Sterling, R.K.; et al. Distinct phenotype and function of circulating Vdelta1+ and Vdelta2+ gammadeltaT-cells in acute and chronic hepatitis B. PLoS Pathog. 2019, 15, e1007715. [CrossRef] [PubMed]

250. Cannizzo, E.S.; Tincati, C.; Binda, F.; Ronzi, P.; Cazzaniga, F.A.; Antinori, S.; d'Arminio Monforte, A.; Marchetti, G.; Milazzo, L. Unconventional T cells in chronic hepatitis B patients on long-term suppressive therapy with tenofovir followed by a Peg-IFN add-on strategy: A randomized study. J. Viral Hepat. 2018, 25, 381-390. [CrossRef]

251. Chen, M.; Hu, P.; Ling, N.; Peng, H.; Lei, Y.; Hu, H.; Zhang, D.; Ren, H. Enhanced functions of peripheral gammadelta T cells in chronic hepatitis B infection during interferon alpha treatment in vivo and in vitro. PLoS ONE 2015, 10, e0120086. [CrossRef]

252. Chen, M.; Hu, P.; Peng, H.; Zeng, W.; Shi, X.; Lei, Y.; Hu, H.; Zhang, D.; Ren, H. Enhanced peripheral gammadeltaT cells cytotoxicity potential in patients with $\mathrm{HBV}$-associated acute-on-chronic liver failure might contribute to the disease progression. J. Clin. Immunol. 2012, 32, 877-885. [CrossRef]

253. Bayram, A.; Ozkur, A.; Erkilic, S. Prevalence of human cytomegalovirus co-infection in patients with chronic viral hepatitis B and C: A comparison of clinical and histological aspects. J. Clin. Virol. 2009, 45, 212-217. [CrossRef]

254. Beziat, V.; Dalgard, O.; Asselah, T.; Halfon, P.; Bedossa, P.; Boudifa, A.; Hervier, B.; Theodorou, I.; Martinot, M.; Debre, P.; et al. CMV drives clonal expansion of NKG2C+ NK cells expressing self-specific KIRs in chronic hepatitis patients. Eur. J. Immunol. 2012, 42, 447-457. [CrossRef]

255. Kamar, N.; Pischke, S. Acute and Persistent Hepatitis E Virus Genotype 3 and 4 Infection: Clinical Features, Pathogenesis, and Treatment. Cold Spring Harb. Perspect. Med. 2018, 9, a031672. [CrossRef] [PubMed]

256. Barrague, H.; Fontaine, J.; Abravanel, F.; Maure, E.; Peron, J.M.; Alric, L.; Dubois, M.; Izopet, J.; Champagne, E. Mobilization of gammadelta T Cells and IL-10 Production at the Acute Phase of Hepatitis E Virus Infection in Cytomegalovirus Carriers. J. Immunol. 2021, 206, 1027-1038. [CrossRef]

257. Benova, K.; Hanckova, M.; Koci, K.; Kudelova, M.; Betakova, T. T cells and their function in the immune response to viruses. Acta Virol. 2020, 64, 131-143. [CrossRef] [PubMed]

258. Wang, X.; Lin, X.; Zheng, Z.; Lu, B.; Wang, J.; Tan, A.H.; Zhao, M.; Loh, J.T.; Ng, S.W.; Chen, Q.; et al. Host-derived lipids orchestrate pulmonary gammadelta $\mathrm{T}$ cell response to provide early protection against influenza virus infection. Nat. Commun. 2021, 12, 1914. [CrossRef]

259. Qin, G.; Mao, H.; Zheng, J.; Sia, S.F.; Liu, Y.; Chan, P.L.; Lam, K.T.; Peiris, J.S.; Lau, Y.L.; Tu, W. Phosphoantigen-expanded human gammadelta $\mathrm{T}$ cells display potent cytotoxicity against monocyte-derived macrophages infected with human and avian influenza viruses. J. Infect. Dis. 2009, 200, 858-865. [CrossRef] [PubMed]

260. Cantan, B.; Luyt, C.E.; Martin-Loeches, I. Influenza Infections and Emergent Viral Infections in Intensive Care Unit. Semin Respir. Crit. Care Med. 2019, 40, 488-497. [CrossRef]

261. Gotlieb-Stematsky, T.; Rannon, L.; Vonsover, A.; Varsano, N. Stimulation of antibodies to Epstein-Barr virus (EBV) in acute viral infections. Arch. Virol. 1978, 57, 199-204. [CrossRef] [PubMed]

262. Poccia, F.; Agrati, C.; Castilletti, C.; Bordi, L.; Gioia, C.; Horejsh, D.; Ippolito, G.; Chan, P.K.; Hui, D.S.; Sung, J.J.; et al. Anti-severe acute respiratory syndrome coronavirus immune responses: The role played by V gamma $9 \mathrm{~V}$ delta $2 \mathrm{~T}$ cells. J. Infect. Dis. 2006, 193, 1244-1249. [CrossRef]

263. Jouan, Y.; Guillon, A.; Gonzalez, L.; Perez, Y.; Boisseau, C.; Ehrmann, S.; Ferreira, M.; Daix, T.; Jeannet, R.; Francois, B.; et al. Phenotypical and functional alteration of unconventional T cells in severe COVID-19 patients. J. Exp. Med. 2020, 217, e20200872. [CrossRef] [PubMed]

264. Carll, W.C.; Rady, M.Y.; Salomao, M.A.; Patel, B.; Singh, V.P.; Sen, A. Cytomegalovirus haemorrhagic enterocolitis associated with severe infection with COVID-19. BMJ Open Gastroenterol. 2021, 8, e000556. [CrossRef] [PubMed]

265. Saade, A.; Moratelli, G.; Azoulay, E.; Darmon, M. Herpesvirus reactivation during severe COVID-19 and high rate of immune defect. Infect. Dis. Now 2021, 676-679. [CrossRef]

266. Soderberg-Naucler, C. Does reactivation of cytomegalovirus contribute to severe COVID-19 disease? Immun. Ageing 2021, $18,12$. [CrossRef]

267. Solomay, T.V.; Semenenko, T.A.; Filatov, N.N.; Vedunova, S.L.; Lavrov, V.F.; Smirnova, D.I.; Gracheva, A.V.; Faizuloev, E.B. [Reactivation of Epstein-Barr virus (Herpesviridae: Lymphocryptovirus, HHV-4) infection during COVID-19: Epidemiological features]. Vopr. Virusol. 2021, 66, 152-161. [CrossRef]

268. Simonnet, A.; Engelmann, I.; Moreau, A.S.; Garcia, B.; Six, S.; El Kalioubie, A.; Robriquet, L.; Hober, D.; Jourdain, M. High incidence of Epstein-Barr virus, cytomegalovirus, and human-herpes virus-6 reactivations in critically ill patients with COVID-19. Infect. Dis. Now 2021, 51, 296-299. [CrossRef] [PubMed] 
269. Howard, J.; Zaidi, I.; Loizon, S.; Mercereau-Puijalon, O.; Dechanet-Merville, J.; Mamani-Matsuda, M. Human Vgamma9Vdelta2 T Lymphocytes in the Immune Response to P. falciparum Infection. Front. Immunol. 2018, 9, 2760. [CrossRef]

270. Hviid, L.; Smith-Togobo, C.; Willcox, B.E. Human Vdelta1 $\left(^{+}\right)$T Cells in the Immune Response to Plasmodium falciparum Infection. Front. Immunol. 2019, 10, 259. [CrossRef] [PubMed]

271. Deroost, K.; Langhorne, J. Gamma/Delta T Cells and Their Role in Protection Against Malaria. Front. Immunol. 2018, 9, 2973. [CrossRef]

272. Jagannathan, P.; Kim, C.C.; Greenhouse, B.; Nankya, F.; Bowen, K.; Eccles-James, I.; Muhindo, M.K.; Arinaitwe, E.; Tappero, J.W.; Kamya, M.R.; et al. Loss and dysfunction of Vdelta2 $\left.{ }^{+}\right)$gammadelta T cells are associated with clinical tolerance to malaria. Sci. Transl. Med. 2014, 6, 251ra117. [CrossRef] [PubMed]

273. Jagannathan, P.; Lutwama, F.; Boyle, M.J.; Nankya, F.; Farrington, L.A.; McIntyre, T.I.; Bowen, K.; Naluwu, K.; Nalubega, M.; Musinguzi, K.; et al. Vdelta2+ T cell response to malaria correlates with protection from infection but is attenuated with repeated exposure. Sci. Rep. 2017, 7, 11487. [CrossRef]

274. Farrington, L.; Vance, H.; Rek, J.; Prahl, M.; Jagannathan, P.; Katureebe, A.; Arinaitwe, E.; Kamya, M.R.; Dorsey, G.; Feeney, M.E. Both inflammatory and regulatory cytokine responses to malaria are blunted with increasing age in highly exposed children. Malar. J. 2017, 16, 499. [CrossRef]

275. Farrington, L.A.; Jagannathan, P.; McIntyre, T.I.; Vance, H.M.; Bowen, K.; Boyle, M.J.; Nankya, F.; Wamala, S.; Auma, A.; Nalubega, M.; et al. Frequent Malaria Drives Progressive Vdelta2 T-Cell Loss, Dysfunction, and CD16 Up-regulation During Early Childhood. J. Infect. Dis. 2016, 213, 1483-1490. [CrossRef]

276. Martini, F.; Paglia, M.G.; Montesano, C.; Enders, P.J.; Gentile, M.; Pauza, C.D.; Gioia, C.; Colizzi, V.; Narciso, P.; Pucillo, L.P.; et al. $\mathrm{V}$ gamma $9 \mathrm{~V}$ delta $2 \mathrm{~T}$-cell anergy and complementarity-determining region 3-specific depletion during paroxysm of nonendemic malaria infection. Infect. Immun. 2003, 71, 2945-2949. [CrossRef] [PubMed]

277. Guenot, M.; Loizon, S.; Howard, J.; Costa, G.; Baker, D.A.; Mohabeer, S.Y.; Troye-Blomberg, M.; Moreau, J.F.; Dechanet-Merville, J.; Mercereau-Puijalon, O.; et al. Phosphoantigen Burst upon Plasmodium falciparum Schizont Rupture Can Distantly Activate Vgamma9Vdelta2 T Cells. Infect. Immun. 2015, 83, 3816-3824. [CrossRef]

278. Costa, G.; Loizon, S.; Guenot, M.; Mocan, I.; Halary, F.; de Saint-Basile, G.; Pitard, V.; Dechanet-Merville, J.; Moreau, J.F.; Troye-Blomberg, M.; et al. Control of Plasmodium falciparum erythrocytic cycle: Gammadelta T cells target the red blood cell-invasive merozoites. Blood 2011, 118, 6952-6962. [CrossRef] [PubMed]

279. Junqueira, C.; Polidoro, R.B.; Castro, G.; Absalon, S.; Liang, Z.; Sen Santara, S.; Crespo, A.; Pereira, D.B.; Gazzinelli, R.T.; Dvorin, J.D.; et al. gammadelta T cells suppress Plasmodium falciparum blood-stage infection by direct killing and phagocytosis. Nat. Immunol. 2021, 22, 347-357. [CrossRef]

280. Farrington, L.A.; Callaway, P.C.; Vance, H.M.; Baskevitch, K.; Lutz, E.; Warrier, L.; McIntyre, T.I.; Budker, R.; Jagannathan, P.; Nankya, F.; et al. Opsonized antigen activates Vdelta2+ T cells via CD16/FCgammaRIIIa in individuals with chronic malaria exposure. PLoS Pathog. 2020, 16, e1008997. [CrossRef]

281. Hviid, L.; Kurtzhals, J.A.; Adabayeri, V.; Loizon, S.; Kemp, K.; Goka, B.Q.; Lim, A.; Mercereau-Puijalon, O.; Akanmori, B.D.; Behr, C. Perturbation and proinflammatory type activation of $\mathrm{V}$ delta $1\left(^{+}\right)$gamma delta $\mathrm{T}$ cells in African children with Plasmodium falciparum malaria. Infect. Immun. 2001, 69, 3190-3196. [CrossRef] [PubMed]

282. Worku, S.; Bjorkman, A.; Troye-Blomberg, M.; Jemaneh, L.; Farnert, A.; Christensson, B. Lymphocyte activation and subset redistribution in the peripheral blood in acute malaria illness: Distinct gammadelta+ $\mathrm{T}$ cell patterns in Plasmodium falciparum and P. vivax infections. Clin. Exp. Immunol. 1997, 108, 34-41. [CrossRef]

283. Taniguchi, T.; Md Mannoor, K.; Nonaka, D.; Toma, H.; Li, C.; Narita, M.; Vanisaveth, V.; Kano, S.; Takahashi, M.; Watanabe, H. A Unique Subset of gammadelta T Cells Expands and Produces IL-10 in Patients with Naturally Acquired Immunity against Falciparum Malaria. Front. Microbiol. 2017, 8, 1288. [CrossRef] [PubMed]

284. Rasti, N.; Falk, K.I.; Donati, D.; Gyan, B.A.; Goka, B.Q.; Troye-Blomberg, M.; Akanmori, B.D.; Kurtzhals, J.A.; Dodoo, D.; Consolini, R.; et al. Circulating epstein-barr virus in children living in malaria-endemic areas. Scand. J. Immunol. 2005, 61, 461-465. [CrossRef] [PubMed]

285. Yone, C.L.; Kube, D.; Kremsner, P.G.; Luty, A.J. Persistent Epstein-Barr viral reactivation in young African children with a history of severe Plasmodium falciparum malaria. Trans. R Soc. Trop. Med. Hyg. 2006, 100, 669-676. [CrossRef] [PubMed]

286. Moormann, A.M.; Snider, C.J.; Chelimo, K. The company malaria keeps: How co-infection with Epstein-Barr virus leads to endemic Burkitt lymphoma. Curr. Opin. Infect. Dis. 2011, 24, 435-441. [CrossRef]

287. Chene, A.; Donati, D.; Guerreiro-Cacais, A.O.; Levitsky, V.; Chen, Q.; Falk, K.I.; Orem, J.; Kironde, F.; Wahlgren, M.; Bejarano, M.T. A molecular link between malaria and Epstein-Barr virus reactivation. PLoS Pathog. 2007, 3, e80. [CrossRef] [PubMed]

288. Chene, A.; Nylen, S.; Donati, D.; Bejarano, M.T.; Kironde, F.; Wahlgren, M.; Falk, K.I. Effect of acute Plasmodium falciparum malaria on reactivation and shedding of the eight human herpes viruses. PLoS ONE 2011, 6, e26266. [CrossRef]

289. Donati, D.; Espmark, E.; Kironde, F.; Mbidde, E.K.; Kamya, M.; Lundkvist, A.; Wahlgren, M.; Bejarano, M.T.; Falk, K.I. Clearance of circulating Epstein-Barr virus DNA in children with acute malaria after antimalaria treatment. J. Infect. Dis. 2006, 193, 971-977. [CrossRef]

290. Hviid, L.; Kemp, K. What is the cause of lymphopenia in malaria? Infect. Immun. 2000, 68, 6087-6089. [CrossRef] 
291. Goodier, M.; Krause-Jauer, M.; Sanni, A.; Massougbodji, A.; Sadeler, B.C.; Mitchell, G.H.; Modolell, M.; Eichmann, K.; Langhorne, J. Gamma delta T cells in the peripheral blood of individuals from an area of holoendemic Plasmodium falciparum transmission. Trans. R Soc. Trop. Med. Hyg. 1993, 87, 692-696. [CrossRef]

292. Jomaa, H.; Feurle, J.; Luhs, K.; Kunzmann, V.; Tony, H.P.; Herderich, M.; Wilhelm, M. Vgamma9/Vdelta2 T cell activation induced by bacterial low molecular mass compounds depends on the 1-deoxy-D-xylulose 5-phosphate pathway of isoprenoid biosynthesis. FEMS Immunol. Med. Microbiol. 1999, 25, 371-378. [CrossRef]

293. Morita, C.T.; Mariuzza, R.A.; Brenner, M.B. Antigen recognition by human gamma delta T cells: Pattern recognition by the adaptive immune system. Springer Semin. Immunopathol. 2000, 22, 191-217. [CrossRef] [PubMed]

294. Shen, L.; Huang, D.; Qaqish, A.; Frencher, J.; Yang, R.; Shen, H.; Chen, Z.W. Fast-acting gammadelta T-cell subpopulation and protective immunity against infections. Immunol. Rev. 2020, 298, 254-263. [CrossRef]

295. Shen, Y.; Zhou, D.; Qiu, L.; Lai, X.; Simon, M.; Shen, L.; Kou, Z.; Wang, Q.; Jiang, L.; Estep, J.; et al. Adaptive immune response of Vgamma2Vdelta2+ T cells during mycobacterial infections. Science 2002, 295, 2255-2258. [CrossRef]

296. Tastan, Y.; Arvas, A.; Demir, G.; Alikasifoglu, M.; Gur, E.; Kiray, E. Influence of Bacillus Calmette-Guerin vaccination at birth and 2 months old age on the peripheral blood T-cell subpopulations [gamma/delta and alpha-beta T cell]. Pediatr. Allergy Immunol. 2005, 16, 624-629. [CrossRef]

297. Chen, C.Y.; Yao, S.; Huang, D.; Wei, H.; Sicard, H.; Zeng, G.; Jomaa, H.; Larsen, M.H.; Jacobs, W.R., Jr.; Wang, R.; et al. Phosphoantigen/IL2 expansion and differentiation of Vgamma2Vdelta2 T cells increase resistance to tuberculosis in nonhuman primates. PLoS Pathog. 2013, 9, e1003501. [CrossRef]

298. Spencer, C.T.; Abate, G.; Blazevic, A.; Hoft, D.F. Only a subset of phosphoantigen-responsive gamma9delta2 T cells mediate protective tuberculosis immunity. J. Immunol. 2008, 181, 4471-4484. [CrossRef]

299. Lee, J.; Choi, K.; Olin, M.R.; Cho, S.N.; Molitor, T.W. Gammadelta T cells in immunity induced by Mycobacterium bovis bacillus Calmette-Guerin vaccination. Infect. Immun. 2004, 72, 1504-1511. [CrossRef] [PubMed]

300. Ferluga, J.; Yasmin, H.; Al-Ahdal, M.N.; Bhakta, S.; Kishore, U. Natural and trained innate immunity against Mycobacterium tuberculosis. Immunobiology 2020, 225, 151951. [CrossRef]

301. Meier, N.R.; Battegay, M.; Ottenhoff, T.H.M.; Furrer, H.; Nemeth, J.; Ritz, N. HIV-Infected Patients Developing Tuberculosis Disease Show Early Changes in the Immune Response to Novel Mycobacterium tuberculosis Antigens. Front. Immunol. 2021, 12, 620622. [CrossRef] [PubMed]

302. Ai, J.W.; Ruan, Q.L.; Liu, Q.H.; Zhang, W.H. Updates on the risk factors for latent tuberculosis reactivation and their managements. Emerg. Microbes Infect. 2016, 5, e10. [CrossRef]

303. Adesanya, O.A.; Uche-Orji, C.I.; Adedeji, Y.A.; Joshua, J.I.; Adesola, A.A.; Chukwudike, C.J. Bacillus Calmette-Guerin (BCG): The adroit vaccine. AIMS Microbiol. 2021, 7, 96-113. [CrossRef] [PubMed]

304. Moorlag, S.; Arts, R.J.W.; van Crevel, R.; Netea, M.G. Non-specific effects of BCG vaccine on viral infections. Clin. Microbiol. Infect. 2019, 25, 1473-1478. [CrossRef] [PubMed]

305. Kleen, T.O.; Galdon, A.A.; MacDonald, A.S.; Dalgleish, A.G. Mitigating Coronavirus Induced Dysfunctional Immunity for At-Risk Populations in COVID-19: Trained Immunity, BCG and New Old Friends. Front. Immunol. 2020, 11, 2059. [CrossRef]

306. Netea, M.G.; Giamarellos-Bourboulis, E.J.; Dominguez-Andres, J.; Curtis, N.; van Crevel, R.; van de Veerdonk, F.L.; Bonten, M. Trained Immunity: A Tool for Reducing Susceptibility to and the Severity of SARS-CoV-2 Infection. Cell 2020, 181, 969-977. [CrossRef] [PubMed]

307. Curtis, N.; Sparrow, A.; Ghebreyesus, T.A.; Netea, M.G. Considering BCG vaccination to reduce the impact of COVID-19. Lancet 2020, 395, 1545-1546. [CrossRef]

308. Anderson, F.D.; Ushijima, R.N.; Larson, C.L. Recurrent herpes genitalis. Treatment with Mycobacterium bovis (BCG). Obstet. Gynecol. 1974, 43, 797-805.

309. Hippmann, G.; Wekkeli, M.; Rosenkranz, A.R.; Jarisch, R.; Gotz, M. Nonspecific immune stimulation with BCG in Herpes simplex recidivans. Follow-up 5 to 10 years after BCG vaccination. Wien. Klin Wochenschr 1992, 104, 200-204.

310. Kandasamy, R.; Voysey, M.; McQuaid, F.; de Nie, K.; Ryan, R.; Orr, O.; Uhlig, U.; Sande, C.; O'Connor, D.; Pollard, A.J. Non-specific immunological effects of selected routine childhood immunisations: Systematic review. BMJ 2016, 355, i5225. [CrossRef]

311. Kleinnijenhuis, J.; Quintin, J.; Preijers, F.; Joosten, L.A.; Jacobs, C.; Xavier, R.J.; van der Meer, J.W.; van Crevel, R.; Netea, M.G. BCG-induced trained immunity in NK cells: Role for non-specific protection to infection. Clin. Immunol. 2014, 155, $213-219$. [CrossRef]

312. Barton, E.S.; White, D.W.; Cathelyn, J.S.; Brett-McClellan, K.A.; Engle, M.; Diamond, M.S.; Miller, V.L.; Virgin, H.W.t. Herpesvirus latency confers symbiotic protection from bacterial infection. Nature 2007, 447, 326-329. [CrossRef] [PubMed] 